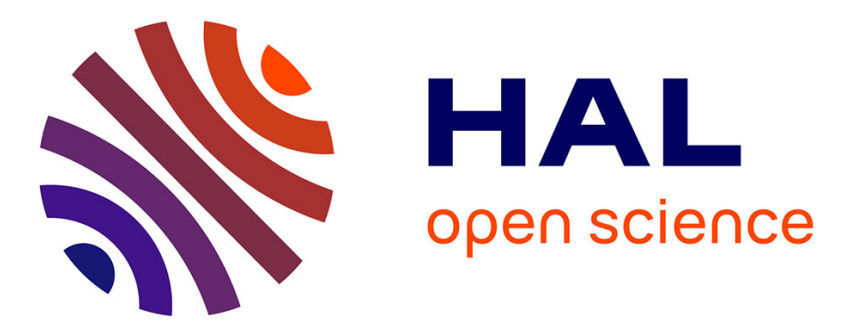

\title{
Modelling and simulation of blood collection systems: improvement of human resources allocation for better cost-effectiveness and reduction of candidate donor abandonment
}

Edgar Alfonso Lizarazo, Xiaolan Xie, Vincent Augusto, Olivier Garraud

\section{To cite this version:}

Edgar Alfonso Lizarazo, Xiaolan Xie, Vincent Augusto, Olivier Garraud. Modelling and simulation of blood collection systems: improvement of human resources allocation for better costeffectiveness and reduction of candidate donor abandonment. Vox Sanguinis, 2013, 104 (3), pp.225-233. 10.1111/vox.12001 . hal-00840560

\author{
HAL Id: hal-00840560 \\ https://hal.science/hal-00840560
}

Submitted on 20 Feb 2014

HAL is a multi-disciplinary open access archive for the deposit and dissemination of scientific research documents, whether they are published or not. The documents may come from teaching and research institutions in France or abroad, or from public or private research centers.
L'archive ouverte pluridisciplinaire HAL, est destinée au dépôt et à la diffusion de documents scientifiques de niveau recherche, publiés ou non, émanant des établissements d'enseignement et de recherche français ou étrangers, des laboratoires publics ou privés. 


\title{
Modelling and simulation of blood collection systems: Improvement of human resources allocation for better cost- effectiveness and reduction of candidate donor abandonment
}

\author{
Alfonso, Edgar ${ }^{(1,5)}$; XIE, XiAolan ${ }^{(1)}$; AUgusto, Vincent ${ }^{(1)}$; GARRAUd, Olivier $^{(2,3}$, \\ 4)* \\ (1) Ecole Nationale Supérieure des Mines de Saint Etienne, Centre CIS ; Département \\ I4S ; IFRESIS-ENSM.SE, IFR 143 ; LIMOS-ROGI CNRS UMR 6158, 158 Cours \\ Fauriel ; 42023 Saint-Étienne Cedex 2, France \\ (2) SFR-IFRESIS, IFR 143 \\ (3) Etablissement Français du Sang Auvergne-Loire, Saint-Etienne Cedex 2, France \\ (4) Groupe Immunité des Muqueuses et Agents Pathogènes, GIMAP - EA 3064, \\ Université de Lyon, Saint-Etienne Cedex 2, France \\ (5) Universidad de La Sabana, School of Engineering, Group Logistic Systems, Campus \\ Universitario Puente del común Km. 7 Autopista Norte, Bogotá D.C., Colombia
}

\begin{abstract}
This study addresses the modelling and simulation of blood collection for fixed blood collection sites in a medium-sized large French city, as well as mobile blood collection in urban and rural environments. Formal Petri net models were used to describe all relevant donor flows of the various blood collection systems; the Petri net models were converted onto discrete-event simulation models, allowing the evaluation of a large number of scenarios and configurations of blood collection systems. Quantitative models were proposed that encompassed all components of the blood collection systems, such as the donor arrival process, resource capacities and performance indicators. Appropriate experimental designs and cost-effectiveness analyses were used to determine the best configurations of human resources and donor appointment strategies. The donor service level depended on both adequate human resources capacity and appropriate appointment strategies. These decisions depend on the distribution during the day of walk-in donors. Models permit to improve management of blood collection; they have now partially entered the real situation, awaiting further implementation.

Keywords:

blood donor flow management ; discrete-event simulation ; health system cost-effectiveness ; petri nets ; transfusion.

\section{Introduction}

Blood collection is organized the national level in France solely by the Etablissement Français $d u$ Sang (EFS, the French National Blood Service). Collection is adjusted to demand to create a national inventory. Demand increases regularly over time in France, where all blood donations are voluntary and unpaid, including plasma collection for fractionation, thus imposing pressure on the EFS and volunteer donors and their representatives. Surveys on generosity and sociology in French blood donation have been carried out by various research organizations (CREDOC 2007, CERPHI 2006 and EFS 2009). These studies [1-3] have uniformly revealed a discrepancy between the intention and action of donating blood despite
\end{abstract}

\footnotetext{
"Corresponding Author: Olivier Garraud : olivier.garraud@efs.sante.fr
} 
acknowledgement of patient needs and appropriate age and physical condition for donation, thus emphasizing the lack of visibility of blood donation organization and publicity. Welcoming blood donors under the best possible conditions therefore represents a challenge to meet increasing demand; revisiting the organization of blood collection in terms of the system capacity and donor appointment strategies may provide a possible solution.

In addition to this increase in demand, the EFS faces pressure from public authorities for cost containment, requiring efficient management of blood collection to provide quality services to donor while keeping blood collection costs under control. Waiting times and donation cycle times are important factors that affect donor retention and recruitment. This study proposes a simulation-based approach for capacity planning of human resources and donor appointment planning.

In France, the medical interview must be conducted and validated by a trained physician without delegation to nurses, while trained nursed perform phlebotomy and blood collection; under certain circumstances, a trained technician is authorized to phlebotomize and collect whole blood (WB) only, under the supervision of a nurse. Collection is carried out at fixed sites ( $15 \%$ of collection) and in mobile collection units ( $85 \%$ of collection). In fixed sites, collections are comprised of all types of donations but specialize in aphaeresis platelet and plasma collection, especially upon appointment. Mobile collections fall into the categories of WB collections (the majority), aphaeresis plasma collection only and mixed collections.

The supply chains of blood products have received increased attention in recent years due to strict technical requirements for temperature control, allotted processing time (no more than $24 \mathrm{~h}$ after collection), requirement for in-process leucoreduction and other factors [4]. The organization of blood supply-chain management also takes into account the capacity of facilities to smoothly process labile blood component through preparation (packed red blood cells, platelet components, fresh frozen plasma or deep freezing of plasma for outsourced fractionation), quality control (input and / or output statistics) and qualification of blood donations. With technological progress and stricter regulation, blood supply chains have substantially changed over time [5]. In the 1980s, Pratt and Grindon [6] presented a computer simulation to study workflow and queuing problems in blood in which donor scheduling strategies were analysed with random arrival at a constant hourly rate to measure system performance.

Here, we sought to evaluate a simulation-based approach for the assessment of performance in both types of collection systems for all types of blood components. We first propose the socalled 'Formal Petri net models' (for a precise definition, refer to the Data S1, Figure S1) of fixed site collection, single mobile blood collection units for WB, and double mobile blood collection units with walk-in WB donors and scheduled plasma donors. We then convert the Petri net models into simulation models with precise descriptions of the important features of blood collection such as the donor arrival processes, noshows / abandonment / deferrals, distribution of collection activity times, relevant human / material resource capacities and performance indicators including global indicators and operational indicators. The Petri net models depend on resource capacity planning decisions and donor appointment strategies that were improved with appropriate experimental design. A cost-effectiveness analysis was performed to determine the best configurations of the collections systems.

\section{Materials and methods}

\section{II.1. Donor walk-in to fixed sites and mobile blood collections}

One fixed site in the city of Saint-Etienne (EFS Auvergne-Loire; 175 000 in-city inhabitants; $\sim 375$ ooo inhabitants within the periphery) principally collects aphaeresis plasma and aphaeresis platelets; it also collects WB upon donor presentation or upon specific need. Approximately 13 ooo blood components are collected at this fixed site annually. Mobile collections are comprised of single collections of WB and/or double collections of blood and aphaeresis plasma, for which plasma donors arrive on appointment. There are no major differences in the donation processes of fixed and mobile sites, which both involve four major steps: Step 1, candidate donors are welcomed by a professional secretary registration, identity confirmation and data completion (the system produces an anonymous number and a file that 
accompanies the donor and the donation). The donor is given a pre-donation questionnaire to complete before interview with a physician. Step 2 consists of a private interview with a physician, review of the questionnaire and completion of additional open-ended questions. When necessary, medical examination occurs during this step; venous or (more frequently) capillary haemoglobin $(\mathrm{Hb})$ determination is performed by the physician who decides whether a temporary or definitive deferral is needed. Step 3 is the donation itself, in which blood component collection is carried out by a trained nurse (all donations) or technician (only WB) based on the physician's instructions. Finally, the donor is supervised in the canteen area in Step 4, where he / she is offered a light meal and a soft drink for smooth recovery and is monitored for rehydration and vagal faints. At all steps, but especially steps 24, donors are sensitized/re sensitized regarding post-donation information.

\section{II.2. Theoretical modelling}

Detailed blood collection process and performances of the blood collection system depend on the type of blood donation and donor behaviours. We thus propose a simulation-based approach for both fixed site and mobile blood collection systems for each blood components. We first propose a formal modelling based on Petri net models of various blood collection processes to take into account blood collection protocols and relevant resource requirements (Data S1, Figure S3). Basically, the model takes into consideration three main elements: all detailed process steps corresponding to collection activities (Whole Blood donation, Aphaeresis plasma collection, Aphaeresis platelet collection), availability of human and material resources (secretaries, physicians, nurses, machines for WB, plasma and platelets donation) and transitions of donors between different process steps.

The Petri net models are then converted into simulation models by combining with quantitative features of blood collection such as donor arrival processes, no-shows-abandondeferrals of donors, distribution of collection activity times, relevant human / material resource capacities and performance indicators (Figure S2). The simulation models are built using the simulation software ARENA (Rockwell Automation Technologies) [7]. A detailed explanation of the model is given as supplemental material (Data S2; refer also Reference 8) [8]. A cost-effectiveness analysis is performed to determine the best configurations of the collection systems.

\section{II.3. Establishment of performance indicators}

Three types of performance indicators are considered: global performance, donor floworiented and resource utilization-based indicators. The global performance indicators for fixed sites and mobile collections include service level, waiting probability and probability of abandonment. Service level is defined as the probability of serving a donor within a waiting time target ' $T$ '. Service level is evaluated in the simulation as the percentage of donors meeting this target. Waiting probability is the percentage of the donors having to wait, and probability of abandonment refers to the percentage of donors who abandon the donation before being seen by a physician.

Donor flow-oriented indicators include (1) number of WB, plasma and platelet donations, (2) number of deferrals per donor type, (3) number of plasma and platelet noshows, (4) number on in-progress donations per donor type, (5) queue times (minimum, mean, maximum) and number of donors waiting for each activity per donor type and (6) mean, minimum and maximum cycle times for each donor type.

\section{II.4. Cost-effectiveness}

We also perform an analysis of cost-effectiveness defined as service as service level divided by total cost. Cost-effective analysis allows us to determine various attainable donor service levels that is the percentage of donors served within a target waiting time, under different budget constraints. Cost-effectiveness is also considered for their service level indicators including the percentage of waiting donors and the percentage of abandonment due to excessive wait time. Solutions are ranked by cost-effectiveness.

The total cost is evaluated in standard cost units (CU) as the sum of three cost components: salary for humanresources $(5 \mathrm{CU} / \mathrm{h}$ for a secretary, $20 \mathrm{CU} / \mathrm{h}$ for a physician,10 $\mathrm{CU} / \mathrm{h}$ for a nurse) activity-related costs (1 CU per registration, $1 \mathrm{CU}$ per medical interview, $3 \mathrm{CU}$ per WB 
collection, 4 CU per plasma collection, $6 \mathrm{CU}$ per platelet collection and $1 \mathrm{CU}$ for light metal), a penalty cost for waiting (1 CU for a WB donor, $2 \mathrm{CU}$ for a plasma or platelet donor) and donor abandonment cost (4 CU).

Cost units for human resources are allocated based on studies by Ministry services [27] and by Professional Networks [9], based on fiscal incomes for various professions comprising of health system servants. For material resources associated with the donation process (automated amortization and unitary devices), we predefined proportions of 3,2 and 1.5 CUs for platelet donation and WB donation, respectively. Penalty costs for waiting are designed to give priority to donors with appointments (plasma and platelet donors).

\section{Results}

III.1. Donor models: arrival process, no-shows, abandonment and deferrals

The blood collection system combines scheduled plasma donor and walk-in WB donors. In our models, the walk-in WB donors arrive according to a non-homogenous Poisson process, and the arrival process of walk-in donors is characterized by a vector of hourly arrival rates for each hour of the time horizon that can be estimated from historical data. The arrival process of plasma (platelet) donors is denoted by the number of donors scheduled for the day or mobile collection session, as well as the appointment time for each donor.

We assumed that the no-shows, the abandonments and deferrals of different donor are mutually independent. After the medical interview, each donor has a probability of being deferred; the probability of deferral (Table 1) is calculated according to the EFS AuvergneLoire yearly statistics extracted from STALOG (INLOG-Haemonetics, Limonest, France).

Each scheduled plasma or platelet donor is associated with a probability of not appearing called no-show probability. Abandonment depends on the patience of each donor (assumed to be exponentially distributed random patience time). When the wait time for the physicians' interview exceeds the patience time of the donor, the donor abandons the donation and exits the system, for more information about patience time and abandon in service systems see reference [10]. We assume that the most important waiting time is for the physician interview, waiting times for the check-in and for collection machines are small enough. Then only waiting for physician interview can make the donor abandon.

\section{III.2. Distribution of activity times}

Probability distributions of times needed for different blood collection activities are given in Table S1. The parameters are selected using maximum likelihood estimation for some activities and through information collected from medical staff for other activities. Probability distributions are estimated by historical data of each activity using field observations and the EFS database.

III.3. Scenarios for walk-in donors at the fixed site

Given that our fixed site is equipped with one secretary slot, two WB stationary devices, five plasma separators, five platelet separators and that it usually operates $8 \mathrm{~h} /$ day from $8 \mathrm{AM}$ to $4 \mathrm{PM}$, and given that abandonment is negligible at fixed sites, we considered various configurations of the number of physicians needed for each period, the number of nurses needed and the appointment strategies for plasma and platelet donations. We consider three arrival scenarios: (A) WB donors mostly arriving in the morning; (B) WB donors mostly arriving by midday; and (C) WB donors mostly arriving in the afternoon. These scenarios are chosen based on observation of historical WB donors' arrival patterns. Table 2 depicts the hourly arrival rates of each scenario.

Since during the study the everyday need for fixed site was nine platelet donations and 22 plasma donations, we modelled 10 appointments strategies (the actual strategy named strategy 1 , plus nine alternatives) (Table 3 ).

We also considered eight plans for human resources and two wait-time targets (10 and 20 min). The eight human resource plans are obtained by assigning one or two physicians to the morning period (8:00 AM-12:00 PM) and the afternoon period (12:00-4:00 PM), plus assigning three or four nurses. 
The 80 configurations combining 10 appointment strategies and eight human resource plans are compared by simulation. Their performance indicators are given in Table 4. All 80 configurations are plotted in a two-dimension plan in (Figure S4) to identify the best configurations, with the $\mathrm{x}$-axis representing the total cost of each solution and the $y$-axis depicting the percentage of donors served within

the target wait time of 10 min (service level). Each plot defines the cost-effectiveness for each configuration.

The cost-effectiveness analysis is based on the performance indicators of Table 4 and the twodimensional plot. Considering the case of waiting time target of $10 \mathrm{~min}$, in Table 4, configurations are ranked according to a costeffectiveness coefficient defined as the radio of service level to the total cost. Although the real configuration ranks in the top $5 / 81$ solutions for scenario A, it performs poorly in scenario B and C. the number of physicians is insufficient in scenario B; the best-performing configuration recommends the presence of two physicians instead of one in the morning session. A top-2 configuration for scenario B can be derived from the real configuration by changing from appointment strategy 1 to appointment strategy 3. Although the best configuration depends on the scenario, configuration \#22 is among the top-performing configurations in all three scenarios. The service level in the fixed site depends not only on adequate planning of human resources but also an appointment strategies for plasma and platelet donors. Configurations \#22 and \#78 include the same number of physicians and the same number of nurses, but apply different appointment scheduling strategies to achieve a service level of $91 Æ 13 \%$ for configuration \#22 and 46Æ65\% for configuration \#78 under scenario C. Cost-effectiveness analysis can achieve a higher service level with fewer human resources and therefore a lower cost. Appointment scheduling strategies 2-4, with contain configurations suitable for the requirement capacity, performed the best out of the 10 strategies under consideration. These strategies recommend uniform distribution of aphaeresis plasma appointment over the entire day and are relatively unaffected by aphaeresis platelet donation appointments. The best configurations also recommend the planning of human resource capacities according to the distribution of WB donor arrivals throughout the day. For scenario $\mathrm{B}$, one additional physician is necessary in the morning session, and for scenario $\mathrm{C}$, one additional physician is necessary either in the morning or in the afternoon, depending on the appointment strategies. In all cases, the presence of three nurses is likely sufficient. In the best-performing configurations, the average wait time of WB donors is longer than that of plasma and platelet donors due to the random arrival of the WB donors in all scenarios and to the higher number of WB donors in scenario B.

In summary, simulation models of fixed site attendance by blood donation candidates allow the identification of adequate human resource capacity and the optimal appointment scheduling strategy necessary to achieve a given service level. For example, for WB arrival scenario A, a $8 \cdot 44 \%$ variation in total cost leads to a $10 \cdot 16 \%$ variation in the service level requirement among the best configurations(\#22 and \#32) with a service target of 10 min. For scenario C, a $4 \cdot 29 \%$ variation in the service level leads to a $6 \cdot 95 \%$ variation in total cost for configurations \#22 and \#24.

III.4. Scenario for donor walk-ins at mobile blood collection

A standard mobile collection requires one secretary slot and is equipped with nine automated devices for WB collection assistance (operated by three nurses), while a large mobile collection unit such as one near a city hall requires two secretary slots and is equipped with 18 WB devices (for six nurses). We consider in this section a large mobile collection with a single arrival scenario defined hourly arrival rates of $(102 ; 47 ; 31 ; 62 ; 67 ; 42 ; 52 ; 61)$ donors for an 8-h service from 10:00 AM to 6:00 PM. We model a single configuration of six nurses, a target wait time of $20 \mathrm{~min}$ and patience time of $60 \mathrm{~min}$. We also consider 25 plans for physicians, varying from four to eight physicians in each shift (10:00 AM-2:00 PM) and (2:00-6:00 PM), and two or three secretaries.

In total, 50 scenarios are compared with the real configuration (Table 5). These scenarios are plotted in a two-dimension plan in (Figure S4). The best configurations are those with three secretaries; two secretaries led to a poorer service level. A better service level and a lower cost 
could be achieved with more physicians in the first shift and less physicians in the second shift. Interestingly, the abandonment probability is slightly higher with three secretaries than with two, since abandonment was based on the wait time for the physician interview. With three secretaries, donors wait less time for secretaries but are expected to wait longer for physicians and thus exhibit a higher probability of abandonment.

\section{Discussion}

A major challenge for blood establishments is achieving self-sufficiency of collected blood components to meet demand [11]. These establishments face a stricter regulation by regulatory authorities for a higher level of safety for blood donor and recipients; quality management systems are constantly improved to better serve all partners $[12,13]$. However, resources have become rarer compared with the general needs; in France, physicians and certified nurses are not enough to meet all needs in the country. Further, health expenditures are increasing dangerously fast while net incomes either stagnate or decrease, complicating efforts for continuous improvements in patient care [14]. The blood donor resources have also become rarer: For various reasons, a very small percentage of adults fulfilling the social and medical conditions effectively give blood ( $\sim 4 \%$ of the estimated population), with only small increases in the number of total donations and the number of donations per donor over time (about 1.9 donations per active donor annually) [1-3]. Meeting blood donor candidate expectations is thus of major importance to ensure regular donation and to avoid abandonment due to excess queuing. Cost-effectiveness is mandatory to achieve a highquality health service and provide satisfaction of every type of 'customer' of the blood establishment [15].

As blood donors are volunteer and unpaid - including for aphaeresis plasma in France - and show up for donation only on the basis of their generosity and civism, it is the blood establishment's duty to pay them respect and to make any possible effort to minimize wait and process time while insuring service and safety. In an attempt to better adjust the actual resources and/or to plan future best-fit personnel hiring, we aimed at modelling systems that best serve the donor candidates and uses the blood establishment resources.

In this article, we modelled various scenarios to welcome donors to fixed sites and to mobile collections with minimum wait time to avoid abandonment, while providing adequate human resource allocations to serve blood donors. Blood donation is largely characterized by peaks in donor presentation during the day, suggesting that human resource allocation should be adapted to this pattern. We built simulation models of blood collection systems in fixed sites and mobiles collection units. Our use of Petri nets for formal modelling of blood collection systems guarantees consistency between the simulation model and the given specifications of our blood collection systems [16]. At least in theory, we confirmed that best and worst configurations of human resources allocations can be assigned to a predefined site and to the most commonly organized mobile collections for the Auvergne-Loire region of the EFS. The main elements and parameters of these models can be adapted to any other French or possibly foreign situation.

While simulation models have been established for long - in general - for blood supply management (inventories) [17-19], they have not been implemented for the collection itself despite a couple of early initiatives in the 1990s: Brennan et al. [20] presented a computer simulation based on a six-bed benchmark clinic to study customer service and productivity issues for American Red Cross bloodmobiles collecting WB; various set-up, staff allocation and work-rule strategies were used to improve the system and further simulations sought to evaluate strategies for scheduling the arrival of blood donors to a Red Cross blood drive [21]. Occasional studies were performed throughout the 2000s, carried out country by country or system by system methodologies integrating simulation and optimization for the calculation and validation of optimal server configuration in transfusion centres in Rome [22], Finland [23], the U.S. Navy [24] and Canada [25]. Hemmelmayr et al. [26] considered a problem faced by the blood bank of the Austrian Red Cross for Eastern Austria and proposed integer programming-based approaches to investigate the potential value of switching from the current vendor-managed inventory to a vendor-managed inventory system. Contrasting with 
the relatively the literature on blood supply chains, the literature on blood collection systems is sparse and barely permits reproducibility.

Our model consider key characteristics of blood collection systems, including collection of various blood components, combinations of random walk-in donors and scheduled donors, stochastic no-shows/abandonment/deferrals and random blood collection activity times. Our Petri nets were accompanied by rigorous modelling of key quantitative components of the systems such as donor arrival processes, no-shows / abandonments / deferrals, resource capacities and performance indicators. Appropriate experimental design and costeffectiveness analysis were used to determine the human resource requirements and to test donor appointment strategies. Next, a survey will be conducted to match our theory with dayto-day situations, including worst-case scenarios such as lack of personnel, bad weather conditions, etc.

This study provides us with useful indication on how to plan human resource allocations during the different period of the day for both the fixed site and the mobile collection. In our system, human resources are common to either service (fixes site and mobile collection) and alternate their duties both types of settings. We used the present model to proceed to readjustments of allocations of resources between the fixed site and the mobile collection during daytime, depending on the predicted numbers of show-up in each configuration; some categories of personnel may now start with one type of setting and move to the other one to fit the need and to avoid unnecessary presence at a time where donor presentation is expected to be weak during daytime.

\section{Acknowledgements}

The authors are grateful to MM. Jean Casteuble and Christophe Labare; to Drs Catherine Argaud, Patricia Chavarin, Fabrice Cognasse and Alain Lefèbvre; to Mss Françoise Boussoulade, Sophie Titoulet and Hélène Favard; and to EFS Auvergne-Loire staff for their help in field studies and data gathering. The first author's research is funded by a $\mathrm{PhD}$ scholarship from the Ecole Nationale Supérieure de Sécurité Sociale, Saint-Etienne, France.

\section{Authorship and conflict of interest statement}

Edgar Alfonso performed the study, analyzed the data and contributed to the writing of the manuscript; Professor Xie designed the study and set up the formal models; he also overviewed the study and co-wrote the manuscript; Doctor Augusto overviewed the study and co-analysed the data and co-wrote the manuscript; Professor Garraud reviewed and adapted the project, reviewed the completed study and co-wrote the article. None of the authors declare any conflict of interest regarding this present study.

\section{References}

[1] CerPhi: Donner son sang en France. 2006. http://www.cerphi.org/var/plain site/storage/original/application/7d 5aabfo3c2a5912f 2520c6b381c6268.pdf

[2] CREDOC: Les Français et le don de sang. 2007. http://www.dondusang.net/content/medias/media12 QWVqpXcurHSmOhH.pdf

[3] EFS: Rapport d'activités 2009. http://www.dondusang.net/rewrite/article/1290/publications/rapport-d-activite2009.htm?idRubrique $=78$

[4] Council of Europe: Guide to the Preparation, Use and Quality Assurance of Blood Components, 16th edn. Strasbourg, France, EDQM, 2011

[5] Pierskalla WP: Supply chain management of blood banks. in Brandeau ML, Sainfort F, Pierskalla WP (eds): Operations Research and Health Care: A Handbook of Methods and Applications. Boston U.S., Kluwer Academic Publishers, 2004:103-45

[6] Pratt ML, Grindon AJ: Computer simulation analysis of blood donor queuing problems. Transfusion 1982; 22:234-237

[7] ARENA version 11.00.00 CPR 7 Copyright (c) 2006 Rockwell Automation Technologies 
[8] Alfonso E, Xie X, Augusto V, et al.: Modeling and simulation of blood collection. Health Care Manag Sci 2012; 15:63-78

[9] UNASA (Réseau national d'associations agréées). 2009.

http://www.unasa.fr/statistiques/revenus-professions-liberales, http://www.plsfrance.org/app/download/4995223361/REVENUS+DES+PROFESSION

S+LIBERALES.pdf? $t=1315566275, p d f ? t=1315566275$, .pdf? $t=1315566275$,

http://www.journaldunet.com/economie/salaire/classement/professionsliberales.shtml

[10] Mandelbaum A, Zeltyn S: the impact of customers patience on delay and abandonment: some empirically-driven experiments with the MMN + G queue. OR Spectrum 2004; 26:377-411

[11] Maniatis A, Adamides E: Blood collection and the labile blood components: what should the regulators ask for? Vox Sang 1998; 74(Suppl 2):523-525

[12] ISBT Guidelines for validation of automated systems in blood establishments: Validation task force of the international society of blood transfusion working party on information technology. Vox Sang 2010; 98(Suppl 1): 1-15

[13] Eyles J, Heddle N, Webert K, et al.: Do expert assessments converge? An exploratory case study of evaluating and managing a blood supply risk. BMC Public Health 2011; 11:666

[14] Waters JH, Ness PM: Patient blood management: A growing challenge and opportunity. ransfusion 2011; 51:902-903

[15] AuBuchon JP, Custer B, Sher G: A comparison of health care and blood supply system structures. Vox Sang 2011; 100:22-35

[16] Proth JM, Xie XL: Petri Nets. A Tool for Design and Management of Manufacturing Systems. Paris, France, John Wiley \& Sons, 1996

[17] Prastacos GP: Blood inventory management: an overview of theory and practice. Manage Sci 1984; 30:777-800

[18] Sirelson V, Brodheim E: A computer planning model for blood platelet production and distribution. Comput Methods Programs Biomed 1991; 35:279-291

[19] Katsaliaki K, Brailsford S: Using simulation to improve the blood supply chain. Journal of the Operational Research Society 2007; 58:219-227

[20] Brennan JE, Golden BL, Rappoport JK: Go with the flow: improving Red Cross bloodmobiles using simulation analysis. Interfaces 1992; 22:1-13

[21] Michaels JD, Brennan JE, Golden BL, et al.: A simulation study of donor scheduling systems for the American Red Cross. Comput Oper Res 1993; 20:199-213

[22] De Angelis V, Felici G, Impelluso P: Integrating simulation optimisation in health care centre management. Eur J Oper Res 2003; 150:101-114

[23] Rytila JS, Spens KM: Using simulation to increase efficiency in blood supply chains. Manag Res News 2006; 29:801-819

[24] Hoyt P, Hutchins J, Lewis D: Improvement of the U.S. Navy Mobile Blood Bank through Simulation Analysis and Forecasting. Washington, D.C., Department of the Navy, 1996

[25] Blake J, Lipton C, Sangster S: An OR based tool to optimize donor flow in blood clinics. Proceedings ORAHS 2007, Saint-Etienne, France, 2007

[26] Hemmelmayr V, Doerner KF, Hartl RF, et al.: Delivery strategies for blood products supplies. OR Spectrum 2009; 31:707-725

[27] Ministère de l'Economie, de l'industrie et de l'emploi. Chiffres-clés des activités libérales. 2009. http://www.pme.gouv.fr/economie/entreprises/act liberales.pdf 
Figures

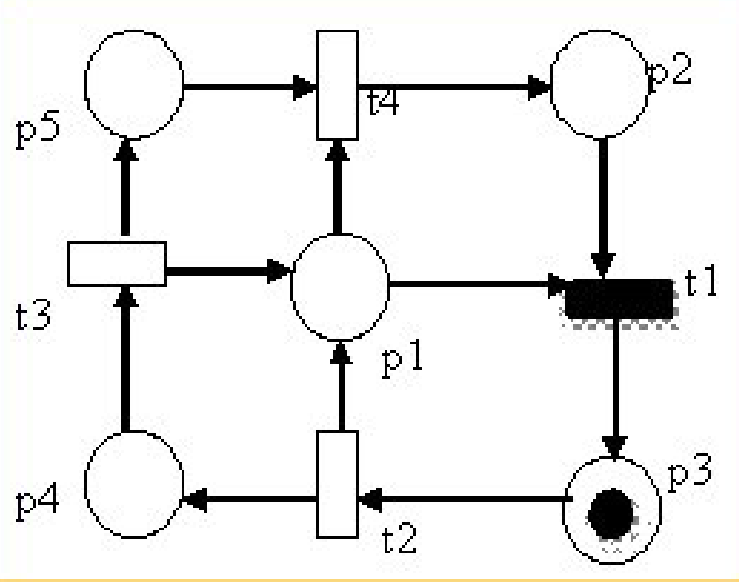

Figure S1: A Petri net given as a model.

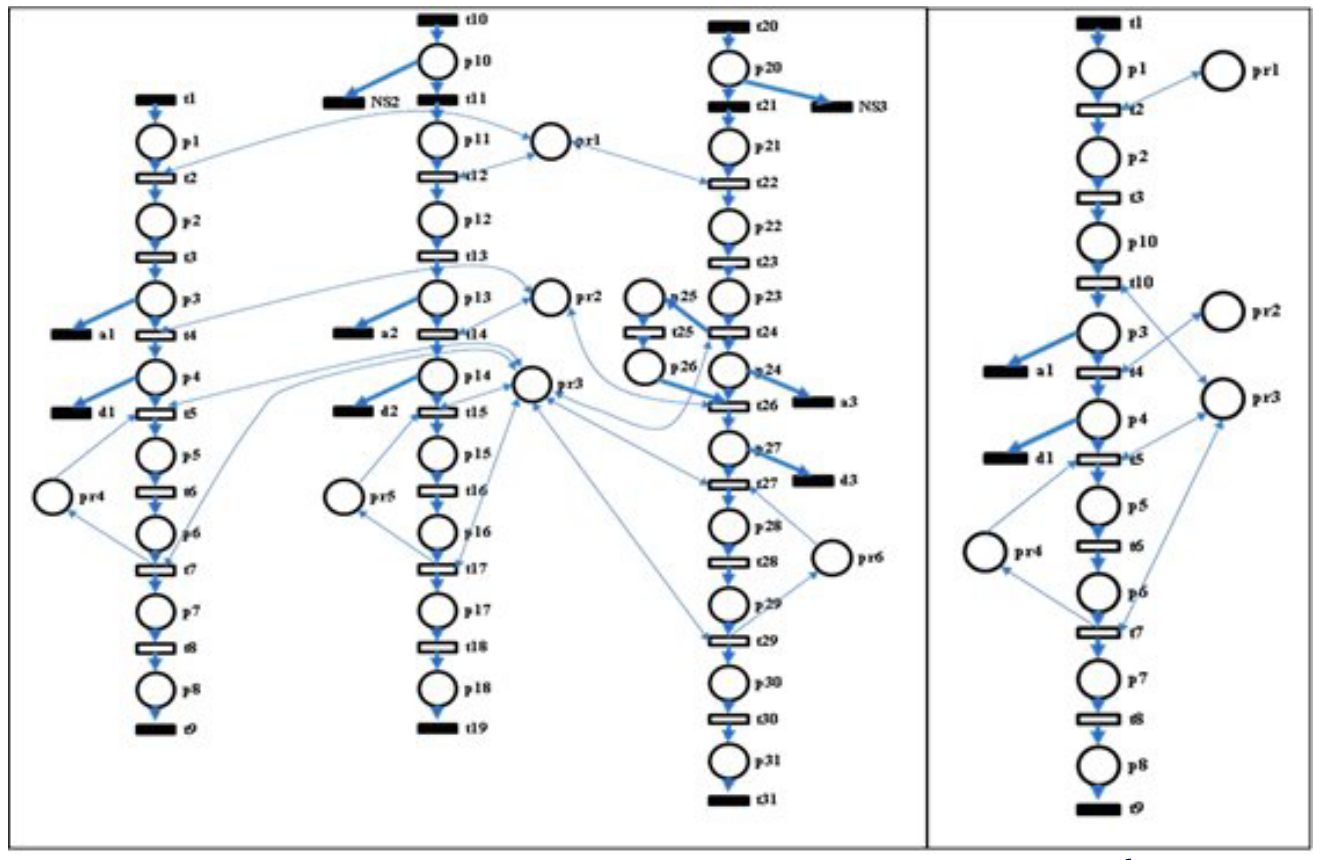

$2 \mathrm{a}$

$2 \mathrm{~b}$

Figure S2: Petri net models for donation at the fixed site (a) and at the generic mobile collection site (b). 


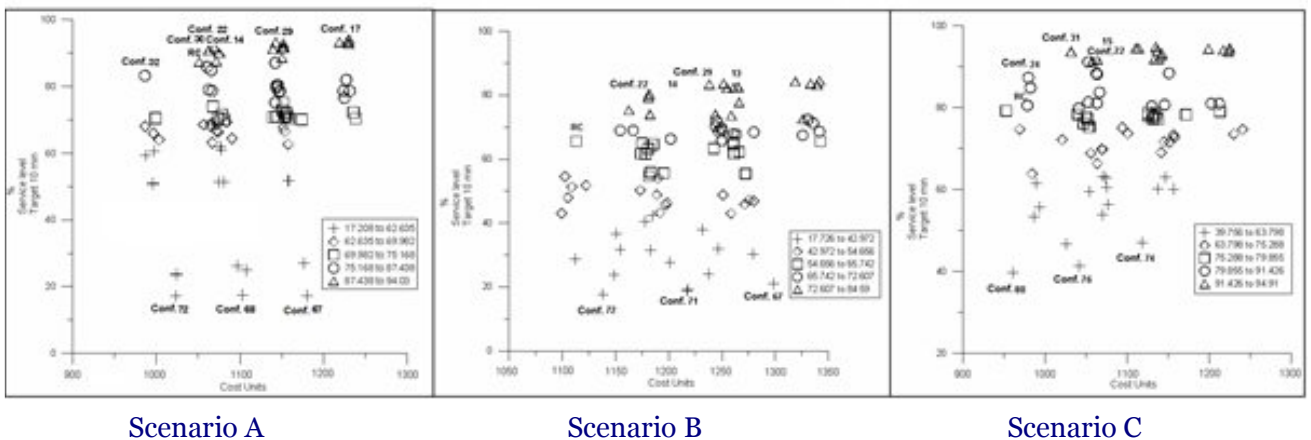

Figure $S_{3}$ : Cost-effectiveness for fixed site collection under donation scenarios $A(a)$, $B(b)$, and $C(c)$.
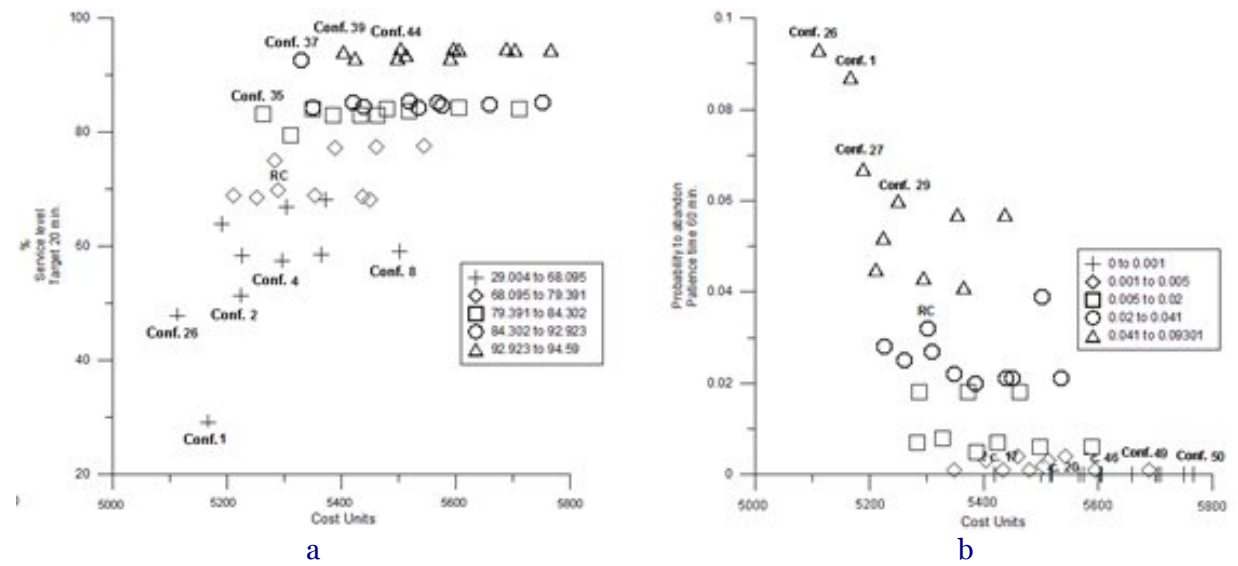

Figure S4: Cost-effectiveness for mobile collection 
Tables

Table 1: No-show and deferral probability

\begin{tabular}{|c|c|c|c|c|c|c|}
\hline & \multicolumn{3}{|c|}{ Deferral probability (\%) } & \multicolumn{3}{|c|}{ No-show probability (\%), } \\
\hline & $\begin{array}{l}\text { Whole } \\
\text { Blood }\end{array}$ & $\begin{array}{l}\text { Plas } \\
\text { ma }\end{array}$ & $\begin{array}{l}\text { Plate } \\
\text { let. }\end{array}$ & $\begin{array}{l}\text { Whole } \\
\text { Blood }\end{array}$ & $\begin{array}{l}\text { Plas } \\
\text { ma }\end{array}$ & $\begin{array}{l}\text { Plate } \\
\text { let }\end{array}$ \\
\hline Fixed site & 10.0 & 1.9. & 2.8 & $\bar{\Delta}$ & 4.3. & 1.0 \\
\hline $\begin{array}{l}\text { Mobile } \\
\text { collection }\end{array}$ & .11 .2 & 2.6 & $\overline{\Delta A}$ & $\overline{-1}$ & $-4 \cdot 3$ & $\overline{\Delta A}$ \\
\hline
\end{tabular}

Table 2: Scenarios for hourly arrival rates (donors/hour) of whole blood donors at the fixed site

\begin{tabular}{|c|c|c|c|c|c|c|c|c|c|}
\hline Scenario & $\begin{array}{l}8 \\
h \\
h\end{array}$ & $\begin{array}{l}9 \\
h\end{array}$ & $\begin{array}{l}10 \\
h\end{array}$ & $\begin{array}{l}11 \\
h\end{array}$ & $\begin{array}{l}12 \\
h\end{array}$ & $\begin{array}{l}13 \\
h\end{array}$ & $\begin{array}{l}14 \\
h\end{array}$ & $\begin{array}{l}15 \\
h\end{array}$ & Total \\
\hline$A$ & 6 & 2. & 5 & 1. & $O_{\Delta}$ & 3. & 1. & $O$ & 18 \\
\hline$B_{\Delta}$ & 3. & 3. & $A_{A}$ & .10. & 5 & 1. & 3 & 2 & 31. \\
\hline$C_{\Delta}$ & 1. & $O_{\Delta}$ & $O_{\Delta}$ & 1. & 6 & 2 & 1. & 4 & 15 \\
\hline
\end{tabular}

Mis en forme

Mis en forme

Mis en forme

Mis en forme

Mis en forme

Mis en forme

Mis en forme

Mis en forme

Commentaire [TV1]: We sugg $€$... [4]

Mis en forme

Mis en forme

Mis en forme

Mis en forme

Mis en forme

Mis en forme

Mis en forme

Mis en forme

Mis en forme

Mis en forme

Mis en forme

Mis en forme

Mis en forme

Mis en forme

Mis en forme

Mis en forme

Mis en forme

Mis en forme

Mis en forme

Mis en forme

Mis en forme

Mis en forme

Mis en forme

Mis en forme

Tableau mis en forme

Mis en forme

Mis en forme

Commentaire [TV2]: We sug£ [29]

Mis en forme

Mis en forme

Mis en forme

Mis en forme

Mis en forme

Mis en forme

Mis en forme

Mis en forme

Mis en forme

Mis en forme

Mis en forme

Mis en forme

Mis en forme

Mis en forme

Mis en forme

Mis en forme

Mis en forme

Mis en forme

Mis en forme

Mis en forme

Mis en forme

Mis en forme

Mis en forme

Mis en forme

1


Table 3: Appointment strategies

\begin{tabular}{|c|c|c|}
\hline $\begin{array}{l}\text { Strate } \\
\text { gy\# }\end{array}$ & $\begin{array}{l}\text { Aphaeresis Platelet } \\
\text { donation }\end{array}$ & Aphaeresis plasma donation \\
\hline 1 & $\begin{array}{l}\text { (two2 APTappointments at } \\
\text { 8:oo, } \\
\text { two } 2 \text { APTappointments at } \\
\text { 10:OO, two2 } \\
\text { APTappointments at } \\
\text { noon12:oo, three3 } \\
\text { APTappointments at 2:00 } \\
\text { PM }\end{array}$ & 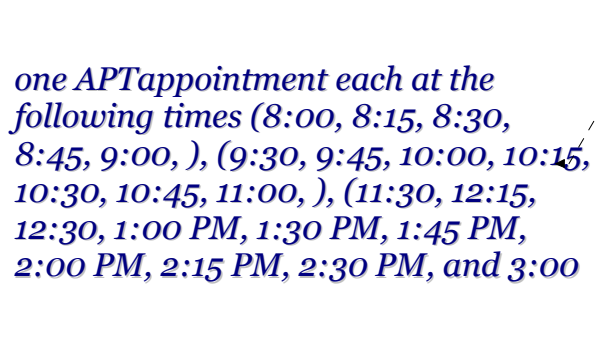 \\
\hline 2 & $\begin{array}{l}\text { one1 aphaeresis platelet } \\
\text { APTappointment every } 45 \\
\min (8: 00 A M-2: 00 \text { PM) }\end{array}$ & $\begin{array}{l}\text { one1 plasma APTappointment every } \\
20 \mathrm{~min} \\
(8: 00 \mathrm{AM}-3: 00 \mathrm{PM}) \text {; }\end{array}$ \\
\hline 3 & $\begin{array}{l}\text { one1 aphaeresis platelet } \\
\text { APTappointment every } 25 \\
\min (8: 00 A M-11: 20)\end{array}$ & $\begin{array}{l}\text { one1 plasma APTappointment every } \\
20 \mathrm{~min} \\
(8: 00 \mathrm{AM}-3: 00 \mathrm{PM}) .\end{array}$ \\
\hline 4 & $\begin{array}{l}\text { one1 aphaeresis platelet } \\
\text { APTappointment every } 25 \\
\min (11: 00 A M-2: 20 \text { PM), }\end{array}$ & $\begin{array}{l}\text { one1 plasma APTappointment every } \\
20 \mathrm{~min} \\
(8: 00 \mathrm{AM}-3: 00 \mathrm{PM})\end{array}$ \\
\hline 5 & $\begin{array}{l}\text { one1 aphaeresis platelet } \\
\text { APTappointment every } 45 \\
\min (8: 00 \mathrm{AM}-14: 00 \mathrm{PM})\end{array}$ & $\begin{array}{l}\text { one1 plasma APTappointment every 10 } \\
\text { min } \\
(8: 00 A M-11: 30 P M)\end{array}$ \\
\hline 6 & $\begin{array}{l}\text { one1 aphaeresis platelet } \\
\text { APTappointment every } 45 \\
\min (8: \text { oo } A M-2: \text { oo PM) }\end{array}$ & $\begin{array}{l}\text { one1 plasma APTappointment every } 10 \\
\text { min } \\
(11: 00 A M-2: 30 P M)\end{array}$ \\
\hline 7 & $\begin{array}{l}\text { one1 aphaeresis platelet } \\
\text { APTappointment every } 25 \\
\min (11: 00 A M-2: 20 \text { PM) }\end{array}$ & $\begin{array}{l}\text { one1 plasma APTappointment every } 10 \\
\text { min } \\
(8: 0 o A M-11: 30 A M)\end{array}$ \\
\hline 8 & $\begin{array}{l}\text { one1 aphaeresis platelet } \\
\text { APTappointment every } 25 \\
\min (8: \text { oO } A M-11: 20 \text { PM) }\end{array}$ & $\begin{array}{l}\text { one1 plasma APTappointment every } 10 \\
\text { min } \\
(11: 0 O A M-2: 30 P M)\end{array}$ \\
\hline 9 & $\begin{array}{l}\text { one1 aphaeresis platelet } \\
\text { APTappointment every } 25 \\
\min (8: 00 \text { AMh -- 11:h2O } \\
\text { PM) }\end{array}$ & $\begin{array}{l}\text { one1 plasma APTappointment every } 10 \\
\text { min } \\
(8: 0 o A M h--11: h 30 P M)\end{array}$ \\
\hline 10 & $\begin{array}{l}\text { one1 aphaeresis platelet } \\
\text { APTappointment every } 25\end{array}$ & $\begin{array}{l}\text { one1 plasma APTappointment every } 10 \\
\text { min }\end{array}$ \\
\hline
\end{tabular}

Tableau mis en forme

Mis en forme : Légende Figure, Interligne : simple, Éviter veuves et orphelines, Espacement automatique entre les caractères asiatiques et latins, Espacement automatique entre les caractères asiatiques et les chiffres

Mis en forme : Légende Figure, Interligne : simple, Éviter veuves et orphelines, Espacement automatique entre les caractères asiatiques et latins, Espacement automatique entre les caractères asiatiques et les chiffres

Mis en forme : Légende Figure, Interligne : simple, Éviter veuves et orphelines, Espacement automatique

entre les caractères asiatiques et latins, Espacement automatique entre les caractères asiatiques et les chiffres

Mis en forme : Légende Figure, Interligne : simple, Éviter veuves et orphelines, Espacement automatique entre les caractères asiatiques et latins, Espacement automatique entre les caractères asiatiques et les chiffres

Mis en forme : Légende Figure, Interligne : simple, Éviter veuves et orphelines, Espacement automatique entre les caractères asiatiques et latins, Espacement automatique entre les caractères asiatiques et les chiffres

Mis en forme : Légende Figure, Interligne : simple, Éviter veuves et orphelines, Espacement automatique entre les caractères asiatiques et latins, Espacement automatique entre les caractères asiatiques et les chiffres

Mis en forme : Légende Figure, Interligne : simple, Éviter veuves et orphelines, Espacement automatique entre les caractères asiatiques et latins, Espacement automatique entre les caractères asiatiques et les chiffres

Mis en forme : Légende Figure, Interligne : simple, Éviter veuves et orphelines, Espacement automatique entre les caractères asiatiques et latins, Espacement automatique entre les caractères asiatiques et les chiffres

Mis en forme : Légende Figure, Interligne : simple, Éviter veuves et orphelines, Espacement automatique entre les caractères asiatiques et latins, Espacement automatique entre les caractères asiatiques et les chiffres

Mis en forme : Légende Figure, Interligne : simple, Éviter veuves et orphelines, Espacement automatique entre les caractères asiatiques et latins, Espacement automatique entre les caractères asiatiques et les chiffres 
Table 4: Best and worst configurations for fixed-site blood collection.

\begin{tabular}{|c|c|c|c|c|c|c|c|c|c|c|c|c|c|c|}
\hline \multicolumn{15}{|c|}{ Scenario A: Most |Whole Blood donor candidates arriveals most in the morning } \\
\hline \multirow{3}{*}{$\Delta$} & \multicolumn{4}{|c|}{ Control $\mathbf{\Delta}_{\text {Variables }}$} & \multicolumn{5}{|c|}{ Global indicators } & \multicolumn{4}{|c|}{ Operational indicators (minutes) } & \multirow[b]{2}{*}{$\begin{array}{c}\text { Wait time } \\
\text { platelets }\end{array}$} \\
\hline & Configuration & APT & $\begin{array}{l}\text { Physi } \\
\text { 8h-12h }\end{array}$ & 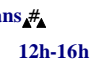 & Nurses $\#_{\boldsymbol{A}_{1}}$ & Service level $(\%)_{\lambda}$ & Wait|probability/ & Rank & Cycle time WB & $\begin{array}{c}\text { Cycle time } \\
\text { plasma }\end{array}$ & $\begin{array}{l}\text { Cycle time } \\
\text { platelets }\end{array}$ & Waiting time WB & $\begin{array}{c}\text { Wait time } \\
\text { plasma }\end{array}$ & \\
\hline & 22 & 3 & 2 & 1 & 3 & $21.66 \pm 1.29$ & $0.55 \pm 0.018_{\Delta}$ & 1 & $38.4 \pm 0.7$ & $74.9 \pm 0.4$ & $111.7 \pm 0.5$ & $4.6 \pm 0.7$ & $1.2 \pm 0.1$ & $2.0 \pm 0.2$ \\
\hline \multirow[t]{2}{*}{ Best } & 30 & 4 & 2 & 1 & 3 & $20.73 \pm 1.31 \Delta$ & $0.50 \pm 0.017_{\Delta}$ & 2 & $38.0 \pm 0.7$ & $75.0 \pm 0.4$ & $111.5 \pm 0.5$ & $4.2 \pm 0.6$ & $1.2 \pm 0.1$ & $2.4 \pm 0.3$ \\
\hline & 32 & 4 & 1 & 1 & 3 & $83.21 \pm 2.33$ & $\rho .65 \pm 0.019$ & 3 & $40.6 \pm 0.7$ & $77.1 \pm 0.5$ & $112.7 \pm 0.8$ & $6.9 \pm 0.7$ & $3.4 \pm 0.4$ & $3.4 \pm 0.6$ \\
\hline \multirow[t]{2}{*}{$\mathrm{AC}^{\mathrm{R}}$} & $R C$ & 1 & 2.2 .2 .1 & 1 & 3 & $87.43 \pm 1.18$ & $\rho .61 \pm 0.01 \sigma_{\Delta}$ & 5 & $38.2 \pm 0.6$ & $75.8 \pm 0.3_{\perp}$ & $114.3 \pm 0.6$ & $4.3 \pm 0.5$ & $2.1 \pm 0.1$ & $4.9 \pm 0.3$ \\
\hline & 71 & 9 & 1 & 2 & 3 & $17.51 \pm 1.77$ & $\rho .91 \pm 0.005_{\perp}$ & 79 & $59.4 \pm 2.3$ & $109.7 \pm 2.8$ & $141.1 \pm 2.6$ & $25.6 \pm 2.3$ & $35.9 \pm 2.8$ & $31.6 \pm 2.5$ \\
\hline \multirow[t]{2}{*}{ Worst } & \$8 8 & 9 & 1 & 1 & 4 & $17.50 \pm 1.99$ & $0.91 \pm 0.00 \sigma_{\mathrm{A}}$ & 80 & $59.8 \pm 2.4$ & $110.1 \pm 2.8$ & $142.2 \pm 2.8$ & $26.0 \pm 2.4$ & $36.2 \pm 2.8$ & $32.4 \pm 2.8$ \\
\hline & 67 & 9 & 1 & 2 & 4 & $17.32 \pm 1.98$ & $0.91 \pm 0.006_{\Delta}$ & 81 & $59.4 \pm 2.2$ & $109.8 \pm 2.8$ & $140.8 \pm 2.5$ & $25.5 \pm 2.2$ & $35.9 \pm 2.7$ & $31.1 \pm 2.5$ \\
\hline \multicolumn{15}{|c|}{ Scenario B: Most Whole Blooddonor candidates arriveals most in the mid-day } \\
\hline \multirow{3}{*}{ Best } & 22 & 3 & 2 & 1 & 3 & $80.39 \pm 2.35$ & $0.66 \pm 0.019$ & 1 & $45.2 \pm 1.8$ & $76.1 \pm 0.6$ & $111.4 \pm 0.5$ & $11.5 \pm 1.7$ & $2.5 \pm 0.5$ & $2.0 \pm 0.1$ \\
\hline & 29 & 4 & 2 & 1 & 3 & $83.41 \pm 2.10$ & $\rho .56 \pm 0.019$ & 2 & $43.6 \pm 1.7$ & $74.8 \pm 0.3$ & $111.1 \pm 0.5$ & $9.7 \pm 1.7$ & $0.9 \pm 0.1$ & $1.8 \pm 0.3$ \\
\hline & 12 & 2 & 2 & 1 & 3 & $79.39 \pm 2.22$ & $\rho .65 \pm 0.016_{\Delta}$ & 3 & $44.2 \pm 1.4$ & $76.6 \pm 0.5$ & $112.3 \pm 0.6$ & $10.3 \pm 1.4$ & $2.7 \pm 0.3$ & $3.0 \pm 0.3$ \\
\hline \multirow[t]{2}{*}{ 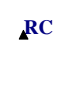 } & $R C$ & 1 & 1.1.1.2 & 1 & 3 & $65.56 \pm 2.6$ & $0.79 \pm 0.015_{\Delta}$ & 18 & $46.5 \pm 1.5$ & $79.2 \pm 0.6$ & $117.6 \pm 0.7$ & $12.6 \pm 1.5$ & $5.3 \pm 0.5$ & $8.4 \pm 0.5$ \\
\hline & 68 & 9 & 1 & 1 & 4 & $\mathbf{1}^{19.17 \pm 2.23}$ & $\rho .93 \pm 0.007$ & 79 & $72.4 \pm 3.5$ & $101.7 \pm 2.1$ & $135.7 \pm 2.2$ & $38.5 \pm 3.5$ & $28.0 \pm 2.1$ & $26.4 \pm 2.2$ \\
\hline \multirow[t]{2}{*}{$\Delta^{\text {Worst }}$} & 72 & 9 & 1 & 1 & 3 & $17.73 \pm 2.05$ & $\rho .93 \pm 0.007$ & 80 & $73.9 \pm 3.4$ & $102.6 \pm 2.0$ & $136.9 \pm 1.9$ & $40.1 \pm 3.4$ & $28.8 \pm 2.0$ & $27.2 \pm 1.9$ \\
\hline & 71 & 9 & 1 & 2 & 3 & $\perp^{18.82 \pm 2.07}$ & $\rho .92 \pm 0.007$ & 81 & $68.6 \pm 2.9$ & $101.7 \pm 1.9$ & $135.1 \pm 1.7$ & $35.0 \pm 2.9$ & $27.9 \pm 1.9$ & $25.4 \pm 1.7$ \\
\hline \multicolumn{15}{|c|}{ 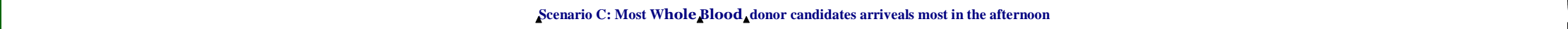 } \\
\hline \multirow{4}{*}{ Best } & 31 & 4 & 1 & 2 & 3 & $23.65 \pm 1.00$ & $0.42 \pm 0.018$ & 1 & $37.2 \pm 0.7$ & $74.4 \pm 0.4$ & $110.4 \pm 0.5_{\perp}$ & $3.6 \pm 0.6$ & $0.7 \pm 0.1_{\Delta}$ & $1.7 \pm 0.2_{\Delta}$ \\
\hline & 24 & 3 & 1 & 1 & 3 & $87.38 \pm 1.68$ & $\rho .61 \pm 0.017$ & 2 & $39.0 \pm 0.7$ & $76.4 \pm 0.4$ & $112.9 \pm 0.5_{\perp}$ & $5.3 \pm 0.7$ & $2.5 \pm 0.2_{\Delta}$ & $3.3 \pm 0.3$ \\
\hline & 15 & 2 & 1 & 2 & 3 & $22.45 \pm 0.97$ & $0.49 \pm 0.017$ & 3 & $37.1 \pm 0.6_{\perp}$ & $74.8 \pm 0.3$ & $112.2 \pm 0.4_{\mathrm{A}}$ & $3.4 \pm 0.6$ & $1.2 \pm 0.1_{\Delta}$ & $2.5 \pm 0.2_{\mathrm{A}}$ \\
\hline & 22 & 3 & 2 & 1 & 3 & $21.13 \pm 1.58$ & $\rho .46 \pm 0.020$ & 4 & $38.4 \pm 0.7$ & $75.4 \pm 0.4$ & $110.2 \pm 0.4$ & $4.5 \pm 0.7$ & $1.6 \pm 0.2$ & $1.0 \pm 0.1_{\Delta}$ \\
\hline $\mathrm{RC}$ & $R C$ & 1 & 1 & 1 & 3 & $80.59+2.0$ & $\rho .66 \pm 0.020$ & 16 & $40.7 \pm 1.11_{\Lambda}$ & $76.9 \pm 0.5 \pm$ & $116.0 \pm 0.6$ & $6.8 \pm 1.0$ & $3.2 \pm 0.4$ & $6.4 \pm 0.4$ \\
\hline ¿Worst & 78 & 10 & 2 & 1 & 3 & $46.65 \pm 3.19$ & $\rho .77 \pm 0.012$ & 78 & $44.9 \pm 1.6$ & $91.3 \pm 1.7$ & $125.0 \pm 2.0$ & $11.1 \pm 1.6$ & $17.4 \pm 1.7$ & $15.4 \pm 2.0$ \\
\hline \multirow[t]{2}{*}{ Worst } & 80 & 10 & 1 & 1 & 3 & $39.76 \pm 3.18$ & $0.84 \pm 0.010$ & 80 & $48.42 \pm 1.58$ & $95.00 \pm 1.77$ & $129.50+2.01$ & $14.66 \pm 1.55$ & $21.08 \pm 1.72$ & $19.92 \pm 1.5$ \\
\hline & 76 & 10 & 1 & 1 & 4 & $41.38+2.92$ & $0.83 \pm 0.010$ & 81 & $47.20 \pm 1.46$ & $93.95+1.64$ & $127.88 \pm 1.66$ & $13.32+1.45$ & $20.22+1.57$ & $18.38 \pm 1$. \\
\hline
\end{tabular}

Each value provides the mean operational indicator given by the simulation model generated through 100 replications to achieve a half-width of 95\% for all global and operational indicators for which the statistics were specified in the output report. APT: Appointment strategy.

\begin{tabular}{|c|c|}
\hline \multicolumn{2}{|c|}{ Commentaire [TV3]: We sug: ... [69] } \\
\hline Mis en forme & $\ldots[71]$ \\
\hline Mis en forme & $\ldots[72]$ \\
\hline Mis en forme & $\ldots[73]$ \\
\hline Mis en forme & $\ldots$ [74] \\
\hline Mis en forme & $\ldots[75]$ \\
\hline Mis en forme & $\ldots[76]$ \\
\hline \multicolumn{2}{|c|}{ Commentaire [TV4]: We sug ... [77 } \\
\hline Mis en forme & $\ldots[78]$ \\
\hline Mis en forme & $\ldots[70]$ \\
\hline \multicolumn{2}{|c|}{ Commentaire [TV5]: We sug: ... [82] } \\
\hline Mis en forme & $\ldots[80]$ \\
\hline Mis en forme & $\ldots[81]$ \\
\hline Mis en forme & $\ldots[83]$ \\
\hline Mis en forme & $\ldots$ [84] \\
\hline Mis en forme & $\ldots[85]$ \\
\hline Mis en forme & $\ldots$ [86] \\
\hline Mis en forme & $\ldots[87]$ \\
\hline Mis en forme & $\ldots[88]$ \\
\hline Mis en forme & $\ldots[89]$ \\
\hline Mis en forme & $\ldots[79]$ \\
\hline Mis en forme & $\ldots[90]$ \\
\hline Mis en forme & $\ldots[91]$ \\
\hline Mis en forme & $\ldots[92]$ \\
\hline Mis en forme & $\ldots[93]$ \\
\hline Mis en forme & $\ldots[95]$ \\
\hline Mis en forme & $\ldots[96]$ \\
\hline Mis en forme & $\ldots[97]$ \\
\hline Mis en forme & $\ldots[98]$ \\
\hline Mis en forme & $\ldots[99]$ \\
\hline Mis en forme & $\ldots[100]$ \\
\hline Mis en forme & $\ldots[94]$ \\
\hline Mis en forme & $\ldots[102]$ \\
\hline Mis en forme & $\ldots[103]$ \\
\hline Mis en forme & $\ldots[104]$ \\
\hline Mis en forme & $\ldots[105]$ \\
\hline Mis en forme & $\ldots[106]$ \\
\hline Mis en forme & $\ldots[107]$ \\
\hline Mis en forme & $\ldots[108]$ \\
\hline Mis en forme & $\ldots[109]$ \\
\hline Mis en forme & $\ldots[101]$ \\
\hline Mis en forme & $\ldots[110]$ \\
\hline
\end{tabular}


Table 5: Best and worst configurations for mobile collection.

\begin{tabular}{|c|c|c|c|c|c|c|c|c|c|c|}
\hline & \multicolumn{4}{|c|}{ Control Variables } & \multicolumn{4}{|c|}{ Global indicators } & \multicolumn{2}{|c|}{ Operational indicators } \\
\hline & \multirow{2}{*}{ Configuration } & \multicolumn{2}{|c|}{ Physicians \# } & \multirow{2}{*}{ Secretaries \# } & \multirow{2}{*}{ Service level (\%) } & \multirow{2}{*}{ Wait probability| } & \multirow{2}{*}{$\begin{array}{c}\text { Probability to } \\
\text { abandon }\end{array}$} & \multirow{2}{*}{ Rank } & \multirow{2}{*}{$\begin{array}{c}\text { Cycle time } \\
\text { Whole Blood }\end{array}$} & \multirow{2}{*}{$\begin{array}{l}\text { Waiting time } \\
\text { Whole Blood }\end{array}$} \\
\hline & & 10h-14h & $14 \mathrm{~h}-18 \mathrm{~h}$ & & & & & & & \\
\hline \multirow{3}{*}{ Best } & 39 & 7 & 5 & 3 & \begin{tabular}{|c|c|}
94.13 & \pm 1.07
\end{tabular} & $0.72 \pm 0.01$ & $0.003 \pm 0.0011$ & 1 & $32.83 \pm 0.37$ & $5.23 \pm 0.35$ \\
\hline & 37 & 6 & 5 & 3 & $92.54 \pm 1.38$ & $0.75 \pm 0.01$ & $0.008 \pm 0.001$ & 2 & $33.46 \pm 0.40$ & $5.96 \pm 0.40$ \\
\hline & 44 & 7 & 6 & 3 & $94.55 \pm 1.04$ & $0.65 \pm 0.01$ & $0.002 \pm 0.001$ & 3 & $31.99 \pm 0.34$ & $4.36 \pm 0.32$ \\
\hline RC & $R C$ & 4.4 .4 .6 & 6.5.6.6. & 2 & $66.88 \pm 1.29$ & $0.88 \pm 0.01$ & $0.032 \pm 0.002$ & 43 & $43 \cdot 32 \pm 0.80$ & $16.36 \pm 0.82$ \\
\hline \multirow{3}{*}{ Worst } & 2 & 4 & 5 & 2 & $51.20 \pm 2.96$ & $0.95 \pm 0.01$ & $0.052 \pm 0.004$ & 49 & $47.58 \pm 0.92$ & $21.17 \pm 1.01$ \\
\hline & 26 & 4 & 4 & 3 & $47.76 \pm 2.82$ & $0.98 \pm 0.01$ & $0.093 \pm 0.006$ & 50 & $45.91 \pm 0.73$ & $20.61 \pm 0.84$ \\
\hline & 1 & 4 & 4 & 2 & $29.00 \pm 3.14$ & $0.99 \pm 0.01$ & o.o87 7 o.oo6 & 51 & $53.64 \pm 1.03$ & $28.14 \pm 1.15$ \\
\hline
\end{tabular}

Each value provides the mean operational indicator given by the simulation model generated through 100 replications to achieve a half-width of 95\% for all global and operational indicators for which the statistics were specified in the output report.
Mis en forme : Légende Figure, Gauche, Interligne : simple, Eviter ponctuation en retrait, Espacement automatique entre les caractères asiatiques et latins, Espacement automatique entre les caractères asiatiques et les chiffres

Commentaire [TV6]: We suggest Commentaire [TV7]: We suggest using consistent bold and italics schemes throughout your table. 
Supplemental_Table 1.: Probability distribution for activity times in minutes.

\begin{tabular}{|c|c|}
\hline Activity & $\begin{array}{l}\text { Probability } \\
\text { distribution }\end{array}$ \\
\hline Registration & NORM $(1.77 ; 0.612)$ \\
\hline $\begin{array}{l}\text { Fixed site screening (including } \\
\text { hemoglobin capillarye Hb test } \\
\text { capillary) }\end{array}$ & TRIA (4; 6; 7.5) \\
\hline Mobile site screening & $\begin{array}{l}2.5+G A M M(0.964 ; \\
2.33)\end{array}$ \\
\hline $\begin{array}{l}\text { Mobile site capillary hemoglobin Hb test } \\
\text { capillary }\end{array}$ & $U N I F(1.34,2)$ \\
\hline Whole blood donation & $\begin{array}{l}9.5+W E I B(4.23 \\
1.82)\end{array}$ \\
\hline Plasma donation & $\operatorname{NORM}(42.8 ; 6.13)$ \\
\hline Platelets donation & $\begin{array}{l}\text { NORM (64.217; } \\
5.4602)\end{array}$ \\
\hline Light meal & $\begin{array}{l}3.5+4^{*} B E T A(1.06 \\
1.31)\end{array}$ \\
\hline Pre-setup whole blood donation & $\operatorname{NORM}(1.6,0.284)$ \\
\hline Post-setup whole blood donation & $U N I F(1,2)$ \\
\hline Pre-setup plasma donor donation & $U N I F(5.5,10.5)$ \\
\hline Post-setup plasma donation & $\operatorname{UNIF}(3.5,7.5)$ \\
\hline Pre-setup platelets donor donation & $U N I F(7.5,12.5)$ \\
\hline Post-setup platelets donation & UNIF $(6.5,10.5)$ \\
\hline
\end{tabular}

Legends: NORM, TRIA, GAMM, UNIF and BETA stand for Normal, Triangle, Gamma, Uniform and Betadistributions, respectively. Further: NORMal (Mean; ,standard deviationSD).: SD - Standard déviation; TRIAngular (mMinimum, , modeMode, maximumMax).: Min - minimum value, Mode - modal value, Max -maximum value; GAMMa (Betascale parameter beta, Alphashape parameter alpha).: Beta - Scale parameter beta / Alpha - Shape parameter alpha; UNIForm (mMinimum, mMaximum).: Min - minimum value, Max - maximum value; BETA (shape parameter aAlpha(1), shape parameter aAlpha(2)).: Alpha1 Shape parameter alpha(1) / Alpha2 - Shape parameter alpha(2); WEIBull (Betascale parameter beta, shape parameter alpha).

\section{Supplemental Text 1: Introduction to the Petri net theory}

This appendix reviews some basic notions and properties of Petri nets that are used in this paper. Refer to [7] for more details.7
Mis en forme: Police :Georgia Anglais (Royaume-Uni)

Mis en forme : Interligne : simple,
Éviter veuves et orphelines, Autoriser
la ponctuation en retrait, Espacement
automatique entre les caractères
asiatiques et latins, Espacement
automatique entre les caractères
asiatiques et les chiffres
Commentaire [TV8]: We suggest
using the footnote symbols specified by
the target journal for these
descriptions:
http://onlinelibrary.wiley.com/journal/
10.1111/\%28ISSN\%291537-
2995/homepage/ForAuthors.html

Mis en forme : Interligne : simple, Eviter veuves et orphelines, Autoriser la ponctuation en retrait, Espacement the target journal for these 10.1111/\%28ISSN\%2915372995/homepage/ForAuthors.html 
A Petri net is a bipartite graph represented by a four-tuple $\left(P, T, F, M_{o}\right)$, where $P$ and $T$ are finite sets of nodes called respectively places and transitions; $F \subseteq(P \times T) \cup(T \times P)$ is a set of directed arcs connecting places to transitions and transitions to places but never nodes of the same type; and $M_{o}: P \rightarrow \boldsymbol{\aleph}$, where $\boldsymbol{\aleph}$ is the set of non negative integers, is an integer vector termed initial marking that associates to each place an integer number of so-called tokens. Tokens are usually used to represent resources and status of moving entities.

Example: Supplemental Figure 1 is a Petri net with five places $\{\mathrm{p} 1, \mathrm{p} 2, \mathrm{p} 3, \mathrm{p} 4, \mathrm{p} 5\}$ and four transitions $\{\mathrm{t} 1$, $\mathrm{t} 2, \mathrm{t} 3, \mathrm{t} 4\}$. The initial marking $M_{o}=[\mathrm{o}, \mathrm{o}, 1, \mathrm{o}, \mathrm{o}]$ assigns 1 token to place $\mathrm{p} 3$.

The set of input (output) transitions of a place $p \in P$ is denoted by $\bullet p(p \bullet)$. The set of input (output) places of a transition $t \in T$ is denoted by $\bullet t(t \bullet)$.

A Petri net models the dynamics of a system by using tokens and rules for evolution of tokens through transition firings. A transition $t$ is said enabled and can be fired under a marking $M$ if and only if $M(p) \geq 1$, for all its input places (i.e. $\forall p \in \bullet t$ ). Firing a transition $t$ consists in removing one token from each of its input places and adding one token to each of its output places. This leads to a new marking $M^{\prime}$ which enables other transitions. A marking $M^{\prime}$ is said reachable from an initial marking $M_{o}$ if there exists a sequence of transitions transforming $M_{o}$ into $M^{\prime}$. The set of all reachable markings and the set of all possible sequences of transitions together model the dynamic behavior of the underlying system.

In this paper, transitions can be either timed or immediate. Timed transitions correspond to activities and are represented by boxes. Immediate transitions are used to represent choices or synchronization and are represented by bars.Alpha[,Stream]): Beta - Scale parameter beta, Alpha - Shape parameter alpha.

\section{Supplemental Text 2: Step by step description of the model}

Modeling with a formal tool like Petri nets allows a comprehensive, step by step, description of all relevant information. This ensures that the simulation models correspond to the specification. The ARENA simulation software permits dynamic statistics and allows user-friendly graphic interface for visualization of system behavior and system performances (Figure 2). The drawbacks of such a simulation-based approach are the lack of closed-form solutions compared to queueing networks based on oversimplified models and increased difficulty in optimizing blood collection configurations compared to deterministic mathematical optimization models that omit uncertainties and dynamic donor behaviors.

The Petri net of fixed-site collection (Supplemental Figure 2a) models three collection processes (WB, plasma, and platelet) and six resource places (pr1 for secretaries, pr2 for physicians, pr3 for nurses, pr4, pr5 and pr6 for WB-, Plasma- and Platelet-machines) and. Transitions are either (i) immediate represented by bars and corresponding to events or (ii) with time represented by boxes and corresponding to collection activities. Places in the three process models indicate different states of donors.

The WB process model is represented by transitions $\{\mathrm{t} 1-\mathrm{t} 9, \mathrm{a} 1, \mathrm{~d} 1\}$ and places $\{\mathrm{p} 1-\mathrm{p} 8\}$ as follows. Transition t1 corresponds to the arrival of a WB donor, $t 2$ the reception and registration with a secretary, $t 3$ the predon questionnaire filling, $\mathrm{t} 4$ the screening by a physician including capillary hemoglobin test, $\mathrm{t} 5$ - $\mathrm{t} 6$ - $\mathrm{t} 7$ correspond to different steps of the donation with t5 representing the preparation of the donor and the whole blood machine (also called pre-setup) and t6 the collection and $t 7$ the end of the donation (also called post-setup), t8 corresponds to the recovery at the canteen area, and t9 the departure of the donor. The donor might abandon the donation (transition a1) if the waiting time becomes too long, the donor can also be deferred (transition d1). During the donation processing t5-t6-t7, a whole blood machine (pr4) is needed while a nurse (pr3) is needed for pre- and post-setup.

The plasma process is represented by transitions $\{\mathrm{t} 1 \mathrm{O}-\mathrm{t} 19, \mathrm{NS} 2, \mathrm{a} 2, \mathrm{~d} 2\}$ and places $\{\mathrm{p} 10-\mathrm{p} 18\}$ and is similar to that of the WB collection except that the donors have been given appointments (scheduled donations) represented by transition t10. A scheduled donor can either arrive (transition t11) or do not show up (transition NS2 for No Show). The platelet process, represented by transitions $\left\{\mathrm{t}_{2} \mathrm{O}-\mathrm{t} 31, \mathrm{NS}_{3}, \mathrm{a}_{3}, \mathrm{~d} 3\right\}$ and places $\{$ p20-p31\}, is slightly more complex. It has scheduled donors (transition t20) with arrivals represented by transition t21 and no shows represented by NS3. Reception/registration and pre-don questionnaire filling are represented by $\mathrm{t} 22$ and t23. Afterward, blood samples are taken by a nurse (t24) and sent to a lab for testing for the suitability of platelet count (t25). Once the lab test is ready, the 
screening (transition t26) with a physician starts. While waiting for lab test and a physician, the donor can abandon the donation (transition a3). The remaining donation process is similar to the collection of whole blood and plasma.

The Petri net model of mobile WB collection slightly differs from that of fixed site collection and is given in Supplemental Figure $2 b$. Due to the large number of new donors, the Hb test was performed in the model after completion of the pre-donation questionnaire \{transition t10\}. The Petri net model of double mobile collection units for WB and plasma can be derived directly from the Petri net model in Supplemental Figure $2 \mathrm{~b}$ by removing the platelet process. 
Police :(Par défaut) Georgia, 11,5 pt, Anglais (Royaume-Uni)

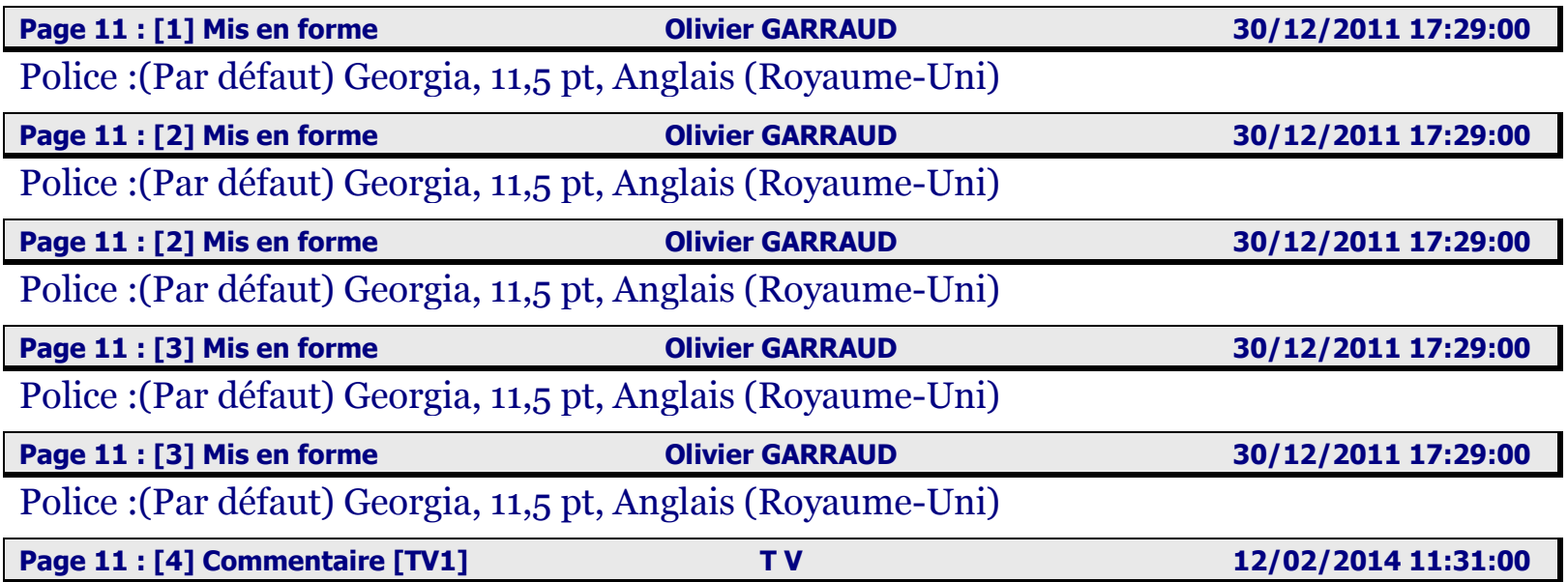

We suggest using footnotes to define the abbreviations used in your tables.

\begin{tabular}{|c|c|c|}
\hline Page $11:$ [5] Mis en forme & Olivier GARRAUD & $30 / 12 / 2011$ 17:29:00 \\
\hline \multicolumn{3}{|c|}{ Police :(Par défaut) Times New Roman } \\
\hline Page 11 : [6] Mis en forme & Olivier GARRAUD & $30 / 12 / 2011$ 17:29:00 \\
\hline \multicolumn{3}{|c|}{ Police :(Par défaut) Georgia, 11,5 pt, Anglais (Royaume-Uni) } \\
\hline Page $11:$ [6] Mis en forme & Olivier GARRAUD & $30 / 12 / 2011$ 17:29:00 \\
\hline \multicolumn{3}{|c|}{ Police :(Par défaut) Georgia, 11,5 pt, Anglais (Royaume-Uni) } \\
\hline Page 11 : [7] Mis en forme & Olivier GARRAUD & $30 / 12 / 2011$ 17:29:00 \\
\hline \multicolumn{3}{|c|}{ Police :(Par défaut) Georgia, 11,5 pt, Anglais (Royaume-Uni) } \\
\hline Page $11:$ [7] Mis en forme & Olivier GARRAUD & $30 / 12 / 2011$ 17:29:00 \\
\hline \multicolumn{3}{|c|}{ Police :(Par défaut) Georgia, 11,5 pt, Anglais (Royaume-Uni) } \\
\hline Page $11:$ [8] Mis en forme & Olivier GARRAUD & $30 / 12 / 201117: 29: 00$ \\
\hline \multicolumn{3}{|c|}{ Police :(Par défaut) Georgia, 11,5 pt, Anglais (Royaume-Uni) } \\
\hline Page $11:$ [8] Mis en forme & Olivier GARRAUD & $30 / 12 / 2011$ 17:29:00 \\
\hline
\end{tabular}

Police :(Par défaut) Georgia, 11,5 pt, Anglais (Royaume-Uni)

\begin{tabular}{|c|c|c|}
\hline Page $11:$ [8] Mis en forme & Olivier GARRAUD & $30 / 12 / 2011$ 17:29:00 \\
\hline \multicolumn{3}{|c|}{ Police :(Par défaut) Georgia, 11,5 pt, Anglais (Royaume-Uni) } \\
\hline Page 11 : [9] Mis en forme & Olivier GARRAUD & $30 / 12 / 2011$ 17:29:00 \\
\hline \multicolumn{3}{|c|}{ Police :(Par défaut) Georgia, 11,5 pt, Anglais (Royaume-Uni) } \\
\hline Page 11 : [9] Mis en forme & Olivier GARRAUD & $30 / 12 / 2011$ 17:29:00 \\
\hline \multicolumn{3}{|c|}{ Police :(Par défaut) Georgia, 11,5 pt, Anglais (Royaume-Uni) } \\
\hline Page 11: [10] Mis en forme & Olivier GARRAUD & $30 / 12 / 2011$ 17:29:00 \\
\hline \multicolumn{3}{|c|}{ Police :(Par défaut) Georgia, 11,5 pt, Anglais (Royaume-Uni) } \\
\hline Page 11 : [10] Mis en forme & Olivier GARRAUD & $30 / 12 / 2011$ 17:29:00 \\
\hline \multicolumn{3}{|c|}{ Police :(Par défaut) Georgia, 11,5 pt, Anglais (Royaume-Uni) } \\
\hline Page 11: [11] Mis en forme & Olivier GARRAUD & $30 / 12 / 2011$ 17:29:00 \\
\hline \multicolumn{3}{|c|}{ Police :(Par défaut) Georgia, 11,5 pt, Anglais (Royaume-Uni) } \\
\hline Page 11: [11] Mis en forme & Olivier GARRAUD & $30 / 12 / 2011$ 17:29:00 \\
\hline \multicolumn{3}{|c|}{ Police :(Par défaut) Georgia, 11,5 pt, Anglais (Royaume-Uni) } \\
\hline Page 11 : [12] Mis en forme & Olivier GARRAUD & $30 / 12 / 2011$ 17:29:00 \\
\hline
\end{tabular}


Police :(Par défaut) Georgia, 11,5 pt, Anglais (Royaume-Uni)

\begin{tabular}{|c|c|}
\hline Page 11 : [13] Mis en forme & $30 / 12 / 2011$ 17:29:00 \\
\hline \multicolumn{2}{|l|}{ Police :(Par défaut) Georgia, 11,5 pt, Anglais (Royaume-Uni) } \\
\hline Page 11 : [13] Mis en forme & $30 / 12 / 2011$ 17:29:00 \\
\hline \multicolumn{2}{|l|}{ Police :(Par défaut) Georgia, 11,5 pt, Anglais (Royaume-Uni) } \\
\hline Page $11:$ [14] Mis en forme & $30 / 12 / 2011$ 17:29:00 \\
\hline \multicolumn{2}{|l|}{ Police :(Par défaut) Georgia, 11,5 pt, Anglais (Royaume-Uni) } \\
\hline $\begin{array}{ll}\text { Page } 11: \text { [14] Mis en forme } & \text { Olivier GARRAUD } \\
\end{array}$ & $30 / 12 / 2011$ 17:29:00 \\
\hline \multicolumn{2}{|l|}{ Police :(Par défaut) Georgia, 11,5 pt, Anglais (Royaume-Uni) } \\
\hline Page $11:$ [15] Mis en forme & $30 / 12 / 2011$ 17:29:00 \\
\hline \multicolumn{2}{|l|}{ Police :(Par défaut) Georgia, 11,5 pt, Anglais (Royaume-Uni) } \\
\hline Page $11:$ [15] Mis en forme $\quad$ Olivier GARRAUD & $30 / 12 / 2011$ 17:29:00 \\
\hline \multicolumn{2}{|l|}{ Police :(Par défaut) Georgia, 11,5 pt, Anglais (Royaume-Uni) } \\
\hline Page $11:[16]$ Mis en forme $\quad$ Olivier GARRAUD & $30 / 12 / 2011$ 17:29:00 \\
\hline \multicolumn{2}{|l|}{ Police :(Par défaut) Georgia, 11,5 pt, Anglais (Royaume-Uni) } \\
\hline Page $11:[16]$ Mis en forme & $30 / 12 / 2011$ 17:29:00 \\
\hline
\end{tabular}

Police :(Par défaut) Georgia, 11,5 pt, Anglais (Royaume-Uni)

\begin{tabular}{|c|c|c|}
\hline Page 11 : [17] Mis en forme & Olivier GARRAUD & $30 / 12 / 2011$ 17:29:00 \\
\hline \multicolumn{3}{|c|}{ Police :(Par défaut) Georgia, 11,5 pt, Anglais (Royaume-Uni) } \\
\hline Page 11 : [17] Mis en forme & Olivier GARRAUD & $30 / 12 / 2011$ 17:29:00 \\
\hline \multicolumn{3}{|c|}{ Police :(Par défaut) Georgia, 11,5 pt, Anglais (Royaume-Uni) } \\
\hline Page 11: [18] Mis en forme & Olivier GARRAUD & $30 / 12 / 2011$ 17:29:00 \\
\hline \multicolumn{3}{|c|}{ Police :(Par défaut) Georgia, 11,5 pt, Anglais (Royaume-Uni) } \\
\hline Page $11:$ [18] Mis en forme & Olivier GARRAUD & $30 / 12 / 2011$ 17:29:00 \\
\hline
\end{tabular}

Police :(Par défaut) Georgia, 11,5 pt, Anglais (Royaume-Uni)

\begin{tabular}{lll}
\hline Page $11:$ [19] Mis en forme & Olivier GARRAUD & $30 / 12 / 2011$ 17:29:00
\end{tabular}

Police :(Par défaut) Georgia, 11,5 pt, Anglais (Royaume-Uni)

Page 11 : [19] Mis en forme Olivier GARRAUD

Police :(Par défaut) Georgia, 11,5 pt, Anglais (Royaume-Uni)

\begin{tabular}{|c|c|c|}
\hline Page 11: [20] Mis en forme & Olivier GARRAUD & $30 / 12 / 2011$ 17:29:00 \\
\hline \multicolumn{3}{|c|}{ Police :(Par défaut) Georgia, 11,5 pt, Anglais (Royaume-Uni) } \\
\hline Page 11 : [20] Mis en forme & Olivier GARRAUD & $30 / 12 / 2011$ 17:29:00 \\
\hline \multicolumn{3}{|c|}{ Police :(Par défaut) Georgia, 11,5 pt, Anglais (Royaume-Uni) } \\
\hline Page $11:$ [21] Mis en forme & Olivier GARRAUD & $30 / 12 / 2011$ 17:29:00 \\
\hline \multicolumn{3}{|c|}{ Police :(Par défaut) Georgia, 11,5 pt, Anglais (Royaume-Uni) } \\
\hline Page $11:$ [21] Mis en forme & Olivier GARRAUD & $30 / 12 / 2011$ 17:29:00 \\
\hline \multicolumn{3}{|c|}{ Police :(Par défaut) Georgia, 11,5 pt, Anglais (Royaume-Uni) } \\
\hline Page 11 : [22] Mis en forme & Olivier GARRAUD & $30 / 12 / 2011$ 17:29:00 \\
\hline \multicolumn{3}{|c|}{ Police :(Par défaut) Georgia, 11,5 pt, Anglais (Royaume-Uni) } \\
\hline Page $11:$ [22] Mis en forme & Olivier GARRAUD & $30 / 12 / 2011$ 17:29:00 \\
\hline \multicolumn{3}{|c|}{ Police :(Par défaut) Georgia, 11,5 pt, Anglais (Royaume-Uni) } \\
\hline Page $11:$ [23] Mis en forme & Olivier GARRAUD & $30 / 12 / 201117: 29: 00$ \\
\hline
\end{tabular}




\begin{tabular}{|c|c|c|}
\hline Page 11: [23] Mis en forme & Olivier GARRAUD & $30 / 12 / 2011$ 17:29:00 \\
\hline \multicolumn{3}{|c|}{ Police :(Par défaut) Georgia, 11,5 pt, Anglais (Royaume-Uni) } \\
\hline Page 11: [24] Mis en forme & Olivier GARRAUD & $30 / 12 / 2011$ 17:29:00 \\
\hline \multicolumn{3}{|c|}{ Police :(Par défaut) Georgia, 11,5 pt, Anglais (Royaume-Uni) } \\
\hline Page 11 : [24] Mis en forme & Olivier GARRAUD & $30 / 12 / 2011$ 17:29:00 \\
\hline \multicolumn{3}{|c|}{ Police :(Par défaut) Georgia, 11,5 pt, Anglais (Royaume-Uni) } \\
\hline Page 11 : [25] Mis en forme & Olivier GARRAUD & $30 / 12 / 2011$ 17:29:00 \\
\hline \multicolumn{3}{|l|}{ Police :(Par défaut) Georgia, 11,5 pt } \\
\hline Page $11:$ [26] Tableau mis en forme & alfonso & $27 / 08 / 201218: 06: 00$ \\
\hline \multicolumn{3}{|l|}{ Tableau mis en forme } \\
\hline Page 11 : [27] Mis en forme & Olivier GARRAUD & $30 / 12 / 2011$ 17:29:00 \\
\hline \multicolumn{3}{|l|}{ Police :(Par défaut) Georgia } \\
\hline Page $11:[28]$ Mis en forme & Olivier GARRAUD & $30 / 12 / 2011$ 17:29:00 \\
\hline \multicolumn{3}{|l|}{ Police :(Par défaut) Georgia, 11,5 pt } \\
\hline Page $11:[28]$ Mis en forme & Olivier GARRAUD & $30 / 12 / 2011$ 17:29:00 \\
\hline \multicolumn{3}{|l|}{ Police :(Par défaut) Georgia, 11,5 pt } \\
\hline Page $11:$ [29] Commentaire [TV2] & T V & 12/02/2014 11:31:00 \\
\hline \multicolumn{3}{|c|}{$\begin{array}{l}\text { We suggest editing your table to have a space between the number and the unit: } 15 \mathrm{~h} \text { instead of } 15 \mathrm{~h} \text {. } \\
\text { We also suggest specifying the units of these calculations (donors/hour?). }\end{array}$} \\
\hline Page 11: [30] Mis en forme & Olivier GARRAUD & $30 / 12 / 2011$ 17:29:00 \\
\hline \multicolumn{3}{|l|}{ Police :(Par défaut) Georgia } \\
\hline Page $11:[31]$ Mis en forme & Olivier GARRAUD & $30 / 12 / 2011$ 17:29:00 \\
\hline \multicolumn{3}{|l|}{ Police :(Par défaut) Georgia, 11,5 pt } \\
\hline Page $11:$ [31] Mis en forme & Olivier GARRAUD & $30 / 12 / 2011$ 17:29:00 \\
\hline \multicolumn{3}{|l|}{ Police :(Par défaut) Georgia, 11,5 pt } \\
\hline Page $11:$ [31] Mis en forme & Olivier GARRAUD & $30 / 12 / 2011$ 17:29:00 \\
\hline \multicolumn{3}{|l|}{ Police :(Par défaut) Georgia, 11,5 pt } \\
\hline Page $11:[32]$ Mis en forme & Olivier GARRAUD & $30 / 12 / 2011$ 17:29:00 \\
\hline \multicolumn{3}{|l|}{ Police :(Par défaut) Georgia, 11,5 pt } \\
\hline Page $11:$ [32] Mis en forme & Olivier GARRAUD & $30 / 12 / 2011$ 17:29:00 \\
\hline \multicolumn{3}{|l|}{ Police :(Par défaut) Georgia, 11,5 pt } \\
\hline Page 11: [32] Mis en forme & Olivier GARRAUD & $30 / 12 / 2011$ 17:29:00 \\
\hline \multicolumn{3}{|l|}{ Police :(Par défaut) Georgia, 11,5 pt } \\
\hline Page $11:$ [33] Mis en forme & Olivier GARRAUD & $30 / 12 / 2011$ 17:29:00 \\
\hline \multicolumn{3}{|l|}{ Police :(Par défaut) Georgia, 11,5 pt } \\
\hline Page $11:$ [33] Mis en forme & Olivier GARRAUD & $30 / 12 / 2011$ 17:29:00 \\
\hline \multicolumn{3}{|l|}{ Police :(Par défaut) Georgia, 11,5 pt } \\
\hline Page $11:$ [33] Mis en forme & Olivier GARRAUD & $30 / 12 / 2011$ 17:29:00 \\
\hline \multicolumn{3}{|l|}{ Police :(Par défaut) Georgia, 11,5 pt } \\
\hline Page $11:$ [34] Mis en forme & Olivier GARRAUD & $30 / 12 / 2011$ 17:29:00 \\
\hline \multicolumn{3}{|l|}{ Police :(Par défaut) Georgia, 11,5 pt } \\
\hline Page $11:$ [34] Mis en forme & Olivier GARRAUD & $30 / 12 / 2011$ 17:29:00 \\
\hline \multicolumn{3}{|l|}{ Police :(Par défaut) Georgia, 11,5 pt } \\
\hline Page 11: [34] Mis en forme & Olivier GARRAUD & $30 / 12 / 2011$ 17:29:00 \\
\hline
\end{tabular}


Police :(Par défaut) Georgia, 11,5 pt

\begin{tabular}{|c|c|c|}
\hline Page 11 : [35] Mis en forme & Olivier GARRAUD & $30 / 12 / 2011$ 17:29:00 \\
\hline \multicolumn{3}{|c|}{ Police :(Par défaut) Georgia, 11,5 pt } \\
\hline Page 11 : [35] Mis en forme & Olivier GARRAUD & $30 / 12 / 2011$ 17:29:00 \\
\hline \multicolumn{3}{|c|}{ Police :(Par défaut) Georgia, 11,5 pt } \\
\hline Page 11 : [35] Mis en forme & Olivier GARRAUD & 30/12/2011 17:29:00 \\
\hline \multicolumn{3}{|c|}{ Police :(Par défaut) Georgia, 11,5 pt } \\
\hline Page 11 : [36] Mis en forme & Olivier GARRAUD & 30/12/2011 17:29:00 \\
\hline \multicolumn{3}{|c|}{ Police :(Par défaut) Georgia, 11,5 pt } \\
\hline Page 11 : [36] Mis en forme & Olivier GARRAUD & 30/12/2011 17:29:00 \\
\hline \multicolumn{3}{|c|}{ Police :(Par défaut) Georgia, 11,5 pt } \\
\hline Page 11 : [36] Mis en forme & Olivier GARRAUD & 30/12/2011 17:29:00 \\
\hline \multicolumn{3}{|c|}{ Police :(Par défaut) Georgia, 11,5 pt } \\
\hline Page 11 : [37] Mis en forme & Olivier GARRAUD & 30/12/2011 17:29:00 \\
\hline \multicolumn{3}{|c|}{ Police :(Par défaut) Georgia, 11,5 pt } \\
\hline Page 11 : [37] Mis en forme & Olivier GARRAUD & 30/12/2011 17:29:00 \\
\hline \multicolumn{3}{|c|}{ Police :(Par défaut) Georgia, 11,5 pt } \\
\hline Page 11 : [37] Mis en forme & Olivier GARRAUD & 30/12/2011 17:29:00 \\
\hline \multicolumn{3}{|c|}{ Police :(Par défaut) Georgia, 11,5 pt } \\
\hline Page 11 : [38] Mis en forme & Olivier GARRAUD & $30 / 12 / 2011$ 17:29:00 \\
\hline \multicolumn{3}{|c|}{ Police :(Par défaut) Georgia, 11,5 pt } \\
\hline Page $11:$ [38] Mis en forme & Olivier GARRAUD & 30/12/2011 17:29:00 \\
\hline \multicolumn{3}{|c|}{ Police :(Par défaut) Georgia, 11,5 pt } \\
\hline Page 11 : [39] Mis en forme & Olivier GARRAUD & $30 / 12 / 2011$ 17:29:00 \\
\hline \multicolumn{3}{|c|}{ Police :(Par défaut) Georgia, 11,5 pt } \\
\hline Page 11 : [39] Mis en forme & Olivier GARRAUD & $30 / 12 / 2011$ 17:29:00 \\
\hline \multicolumn{3}{|c|}{ Police :(Par défaut) Georgia, $11,5 \mathrm{pt}$} \\
\hline Page $11:$ [40] Mis en forme & Olivier GARRAUD & 30/12/2011 17:29:00 \\
\hline \multicolumn{3}{|c|}{ Police :(Par défaut) Georgia, 11,5 pt } \\
\hline Page $11:$ [40] Mis en forme & Olivier GARRAUD & 30/12/2011 17:29:00 \\
\hline \multicolumn{3}{|c|}{ Police :(Par défaut) Georgia, 11,5 pt } \\
\hline Page $11:$ [41] Mis en forme & Olivier GARRAUD & $30 / 12 / 2011$ 17:29:00 \\
\hline \multicolumn{3}{|c|}{ Police :(Par défaut) Georgia, 11,5 pt } \\
\hline Page $11:$ [41] Mis en forme & Olivier GARRAUD & 30/12/2011 17:29:00 \\
\hline \multicolumn{3}{|c|}{ Police :(Par défaut) Georgia, 11,5 pt } \\
\hline Page $11:$ [42] Mis en forme & Olivier GARRAUD & $30 / 12 / 2011$ 17:29:00 \\
\hline \multicolumn{3}{|c|}{ Police :(Par défaut) Georgia, 11,5 pt } \\
\hline Page $11:$ [42] Mis en forme & Olivier GARRAUD & $30 / 12 / 2011$ 17:29:00 \\
\hline \multicolumn{3}{|c|}{ Police :(Par défaut) Georgia, 11,5 pt } \\
\hline Page 11 : [43] Mis en forme & Olivier GARRAUD & $30 / 12 / 2011$ 17:29:00 \\
\hline \multicolumn{3}{|c|}{ Police :(Par défaut) Georgia, $11,5 \mathrm{pt}$} \\
\hline Page 11 : [43] Mis en forme & Olivier GARRAUD & $30 / 12 / 2011$ 17:29:00 \\
\hline \multicolumn{3}{|c|}{ Police :(Par défaut) Georgia, 11,5 pt } \\
\hline Page $11:[44]$ Mis en forme & Olivier GARRAUD & 30/12/2011 17:29:00 \\
\hline
\end{tabular}


Police :(Par défaut) Georgia, 11,5 pt

\begin{tabular}{|c|c|c|}
\hline Page $11:$ [44] Mis en forme & Olivier GARRAUD & $30 / 12 / 2011$ 17:29:00 \\
\hline \multicolumn{3}{|l|}{ Police :(Par défaut) Georgia, 11,5 pt } \\
\hline Page 11 : [45] Mis en forme & Olivier GARRAUD & $30 / 12 / 2011$ 17:29:00 \\
\hline \multicolumn{3}{|l|}{ Police :(Par défaut) Georgia, 11,5 pt } \\
\hline Page $11:[45]$ Mis en forme & Olivier GARRAUD & $30 / 12 / 2011$ 17:29:00 \\
\hline \multicolumn{3}{|l|}{ Police :(Par défaut) Georgia, 11,5 pt } \\
\hline Page $11:$ [46] Mis en forme & Olivier GARRAUD & $30 / 12 / 2011$ 17:29:00 \\
\hline \multicolumn{3}{|l|}{ Police :(Par défaut) Georgia, 11,5 pt } \\
\hline Page 11 : [46] Mis en forme & Olivier GARRAUD & $30 / 12 / 2011$ 17:29:00 \\
\hline \multicolumn{3}{|l|}{ Police :(Par défaut) Georgia, 11,5 pt } \\
\hline Page 11 : [47] Mis en forme & Olivier GARRAUD & $30 / 12 / 2011$ 17:29:00 \\
\hline \multicolumn{3}{|l|}{ Police :(Par défaut) Georgia, 11,5 pt } \\
\hline Page $11:$ [47] Mis en forme & Olivier GARRAUD & $30 / 12 / 2011$ 17:29:00 \\
\hline \multicolumn{3}{|l|}{ Police :(Par défaut) Georgia, 11,5 pt } \\
\hline Page $11:[48]$ Mis en forme & Olivier GARRAUD & 30/12/2011 17:29:00 \\
\hline \multicolumn{3}{|l|}{ Police :(Par défaut) Georgia, 11,5 pt } \\
\hline Page $11:[48]$ Mis en forme & Olivier GARRAUD & 30/12/2011 17:29:00 \\
\hline \multicolumn{3}{|l|}{ Police :(Par défaut) Georgia, 11,5 pt } \\
\hline Page $11:$ [49] Mis en forme & Olivier GARRAUD & 30/12/2011 17:29:00 \\
\hline \multicolumn{3}{|l|}{ Police :(Par défaut) Georgia, 11,5 pt } \\
\hline Page 11: [49] Mis en forme & Olivier GARRAUD & 30/12/2011 17:29:00 \\
\hline \multicolumn{3}{|l|}{ Police :(Par défaut) Georgia, 11,5 pt } \\
\hline Page $11:[50]$ Mis en forme & Olivier GARRAUD & 30/12/2011 17:29:00 \\
\hline \multicolumn{3}{|l|}{ Police :(Par défaut) Georgia, 11,5 pt } \\
\hline Page 11: [50] Mis en forme & Olivier GARRAUD & $30 / 12 / 2011$ 17:29:00 \\
\hline \multicolumn{3}{|l|}{ Police :(Par défaut) Georgia, 11,5 pt } \\
\hline Page 11: [51] Mis en forme & Olivier GARRAUD & 30/12/2011 17:29:00 \\
\hline \multicolumn{3}{|l|}{ Police :(Par défaut) Georgia, 11,5 pt } \\
\hline Page 11: [51] Mis en forme & Olivier GARRAUD & $30 / 12 / 2011$ 17:29:00 \\
\hline \multicolumn{3}{|l|}{ Police :(Par défaut) Georgia, 11,5 pt } \\
\hline Page 11: [52] Mis en forme & Olivier GARRAUD & 30/12/2011 17:29:00 \\
\hline \multicolumn{3}{|l|}{ Police :(Par défaut) Georgia, 11,5 pt } \\
\hline Page 11: [52] Mis en forme & Olivier GARRAUD & 30/12/2011 17:29:00 \\
\hline \multicolumn{3}{|l|}{ Police :(Par défaut) Georgia, 11,5 pt } \\
\hline Page 11: [53] Mis en forme & Olivier GARRAUD & 30/12/2011 17:29:00 \\
\hline \multicolumn{3}{|l|}{ Police :(Par défaut) Georgia, 11,5 pt } \\
\hline Page 11: [53] Mis en forme & Olivier GARRAUD & 30/12/2011 17:29:00 \\
\hline \multicolumn{3}{|l|}{ Police :(Par défaut) Georgia, 11,5 pt } \\
\hline Page $11:$ [54] Mis en forme & Olivier GARRAUD & 30/12/2011 17:29:00 \\
\hline \multicolumn{3}{|l|}{ Police :(Par défaut) Georgia, 11,5 pt } \\
\hline Page $11:$ [54] Mis en forme & Olivier GARRAUD & 30/12/2011 17:29:00 \\
\hline \multicolumn{3}{|l|}{ Police :(Par défaut) Georgia, 11,5 pt } \\
\hline Page $11:$ [55] Mis en forme & Olivier GARRAUD & 30/12/2011 17:29:00 \\
\hline
\end{tabular}


Police :(Par défaut) Georgia, 11,5 pt

\begin{tabular}{|c|c|c|}
\hline Page 11 : [55] Mis en forme & Olivier GARRAUD & $30 / 12 / 2011$ 17:29:00 \\
\hline \multicolumn{3}{|c|}{ Police :(Par défaut) Georgia, 11,5 pt } \\
\hline Page 11 : [56] Mis en forme & Olivier GARRAUD & $30 / 12 / 2011$ 17:29:00 \\
\hline \multicolumn{3}{|c|}{ Police :(Par défaut) Georgia, 11,5 pt } \\
\hline Page 11 : [56] Mis en forme & Olivier GARRAUD & 30/12/2011 17:29:00 \\
\hline \multicolumn{3}{|c|}{ Police :(Par défaut) Georgia, 11,5 pt } \\
\hline Page 11 : [57] Mis en forme & Olivier GARRAUD & 30/12/2011 17:29:00 \\
\hline \multicolumn{3}{|c|}{ Police :(Par défaut) Georgia, 11,5 pt } \\
\hline Page 11 : [57] Mis en forme & Olivier GARRAUD & 30/12/2011 17:29:00 \\
\hline \multicolumn{3}{|c|}{ Police :(Par défaut) Georgia, 11,5 pt } \\
\hline Page 11 : [58] Mis en forme & Olivier GARRAUD & 30/12/2011 17:29:00 \\
\hline \multicolumn{3}{|c|}{ Police :(Par défaut) Georgia, 11,5 pt } \\
\hline Page $11:$ [58] Mis en forme & Olivier GARRAUD & 30/12/2011 17:29:00 \\
\hline \multicolumn{3}{|c|}{ Police :(Par défaut) Georgia, 11,5 pt } \\
\hline Page 11 : [59] Mis en forme & Olivier GARRAUD & 30/12/2011 17:29:00 \\
\hline \multicolumn{3}{|c|}{ Police :(Par défaut) Georgia, 11,5 pt } \\
\hline Page 11 : [59] Mis en forme & Olivier GARRAUD & 30/12/2011 17:29:00 \\
\hline \multicolumn{3}{|c|}{ Police :(Par défaut) Georgia, 11,5 pt } \\
\hline Page 11 : [60] Mis en forme & Olivier GARRAUD & $30 / 12 / 2011$ 17:29:00 \\
\hline \multicolumn{3}{|c|}{ Police :(Par défaut) Georgia, $11,5 \mathrm{pt}$} \\
\hline Page $11:[60]$ Mis en forme & Olivier GARRAUD & 30/12/2011 17:29:00 \\
\hline \multicolumn{3}{|c|}{ Police :(Par défaut) Georgia, 11,5 pt } \\
\hline Page 11 : [61] Mis en forme & Olivier GARRAUD & $30 / 12 / 2011$ 17:29:00 \\
\hline \multicolumn{3}{|c|}{ Police :(Par défaut) Georgia, 11,5 pt } \\
\hline Page 11 : [61] Mis en forme & Olivier GARRAUD & $30 / 12 / 2011$ 17:29:00 \\
\hline \multicolumn{3}{|c|}{ Police :(Par défaut) Georgia, 11,5 pt } \\
\hline Page $11:$ [62] Mis en forme & Olivier GARRAUD & 30/12/2011 17:29:00 \\
\hline \multicolumn{3}{|c|}{ Police :(Par défaut) Georgia, 11,5 pt } \\
\hline Page $11:$ [62] Mis en forme & Olivier GARRAUD & 30/12/2011 17:29:00 \\
\hline \multicolumn{3}{|c|}{ Police :(Par défaut) Georgia, 11,5 pt } \\
\hline Page 11 : [63] Mis en forme & Olivier GARRAUD & $30 / 12 / 2011$ 17:29:00 \\
\hline \multicolumn{3}{|c|}{ Police :(Par défaut) Georgia, 11,5 pt } \\
\hline Page 11 : [63] Mis en forme & Olivier GARRAUD & 30/12/2011 17:29:00 \\
\hline \multicolumn{3}{|c|}{ Police :(Par défaut) Georgia, 11,5 pt } \\
\hline Page 11 : [64] Mis en forme & Olivier GARRAUD & $30 / 12 / 2011$ 17:29:00 \\
\hline \multicolumn{3}{|c|}{ Police :(Par défaut) Georgia, 11,5 pt } \\
\hline Page 11 : [64] Mis en forme & Olivier GARRAUD & $30 / 12 / 2011$ 17:29:00 \\
\hline \multicolumn{3}{|c|}{ Police :(Par défaut) Georgia, 11,5 pt } \\
\hline Page 11 : [65] Mis en forme & Olivier GARRAUD & $30 / 12 / 2011$ 17:29:00 \\
\hline \multicolumn{3}{|c|}{ Police :(Par défaut) Georgia, $11,5 \mathrm{pt}$} \\
\hline Page $11:$ [65] Mis en forme & Olivier GARRAUD & $30 / 12 / 2011$ 17:29:00 \\
\hline \multicolumn{3}{|c|}{ Police :(Par défaut) Georgia, 11,5 pt } \\
\hline Page 11 : [66] Mis en forme & Olivier GARRAUD & $30 / 12 / 2011$ 17:29:00 \\
\hline
\end{tabular}


Police :(Par défaut) Georgia, 11,5 pt

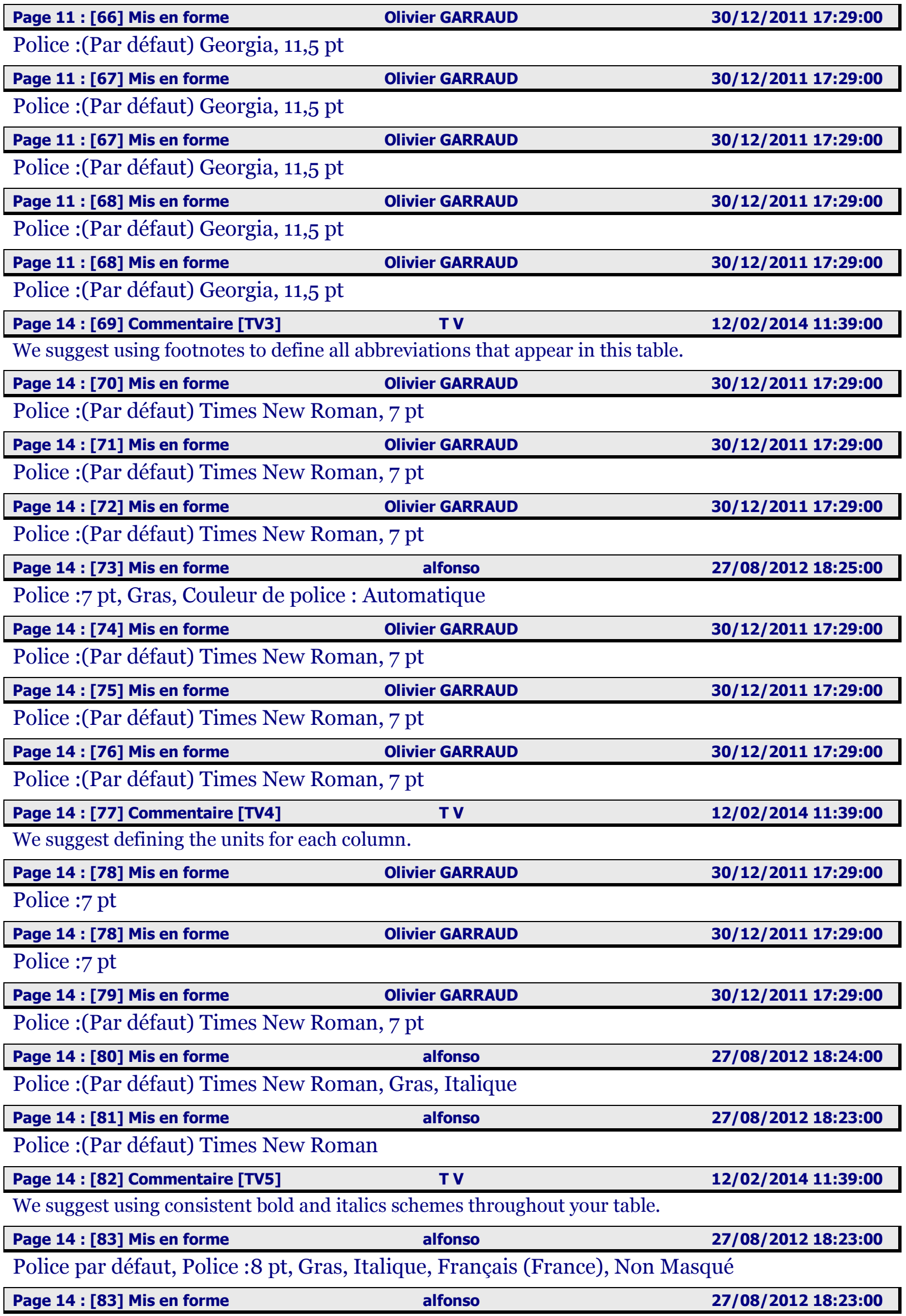


Police par défaut, Police :8 pt, Gras, Italique, Français (France), Non Masqué

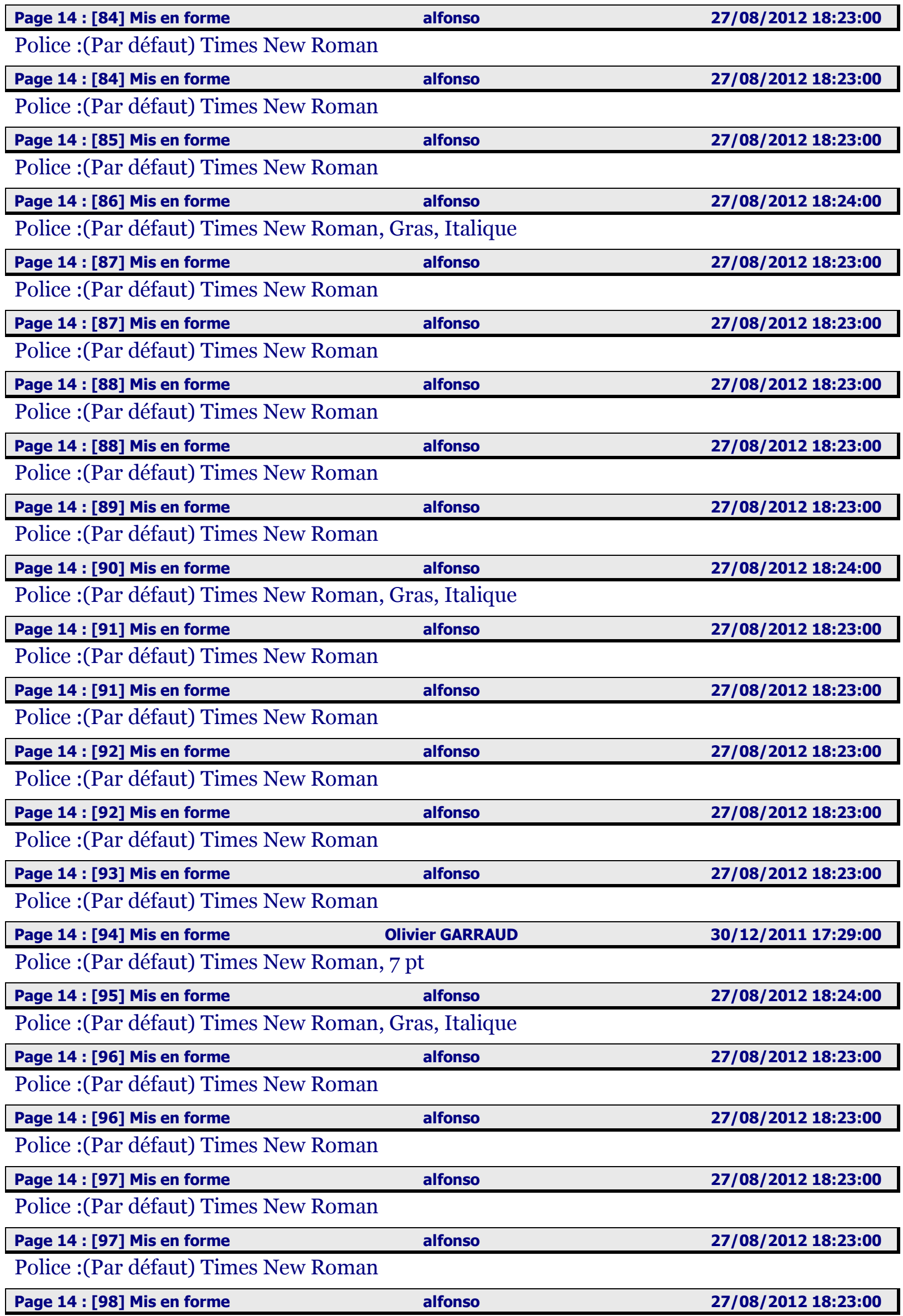


Police :(Par défaut) Times New Roman

\begin{tabular}{|c|c|}
\hline $\begin{array}{ll}\text { Page } 14: \text { : [99] Mis en forme } & \text { alfonso } \\
\end{array}$ & 27/08/2012 18:23:00 \\
\hline \multicolumn{2}{|l|}{ Police :(Par défaut) Times New Roman, Gras, Italique } \\
\hline Page $14:[100]$ Mis en forme & 27/08/2012 18:23:00 \\
\hline \multicolumn{2}{|l|}{ Police :(Par défaut) Times New Roman } \\
\hline Page $14:[101]$ Mis en forme & $30 / 12 / 2011$ 17:29:00 \\
\hline \multicolumn{2}{|l|}{ Police :(Par défaut) Times New Roman, 7 pt } \\
\hline Page 14 : [102] Mis en forme & 27/08/2012 18:24:00 \\
\hline \multicolumn{2}{|l|}{ Police :(Par défaut) Times New Roman, Gras, Italique } \\
\hline Page $14:$ [103] Mis en forme & 27/08/2012 18:23:00 \\
\hline \multicolumn{2}{|l|}{ Police :(Par défaut) Times New Roman } \\
\hline Page 14 : [103] Mis en forme & 27/08/2012 18:23:00 \\
\hline \multicolumn{2}{|l|}{ Police :(Par défaut) Times New Roman } \\
\hline Page $14:$ [104] Mis en forme & 27/08/2012 18:23:00 \\
\hline \multicolumn{2}{|l|}{ Police :(Par défaut) Times New Roman } \\
\hline Page $14:[104]$ Mis en forme & 27/08/2012 18:23:00 \\
\hline \multicolumn{2}{|l|}{ Police :(Par défaut) Times New Roman } \\
\hline $\begin{array}{ll}\text { Page } 14: \text { : }[105] \text { Mis en forme } & \text { alfonso } \\
\end{array}$ & 27/08/2012 18:23:00 \\
\hline \multicolumn{2}{|l|}{ Police :(Par défaut) Times New Roman, Italique } \\
\hline \begin{tabular}{|lc} 
Page $14:$ : [106] Mis en forme & alfonso \\
\end{tabular} & 27/08/2012 18:24:00 \\
\hline \multicolumn{2}{|l|}{ Police :(Par défaut) Times New Roman, Gras, Italique } \\
\hline \begin{tabular}{|lc} 
Page $14:[107]$ Mis en forme & alfonso \\
\end{tabular} & 27/08/2012 18:23:00 \\
\hline \multicolumn{2}{|l|}{ Police :(Par défaut) Times New Roman } \\
\hline Page $14:[107]$ Mis en forme & 27/08/2012 18:23:00 \\
\hline \multicolumn{2}{|l|}{ Police :(Par défaut) Times New Roman } \\
\hline Page $14:[108]$ Mis en forme & 27/08/2012 18:23:00 \\
\hline \multicolumn{2}{|l|}{ Police :(Par défaut) Times New Roman } \\
\hline Page $14:[108]$ Mis en forme & 27/08/2012 18:23:00 \\
\hline \multicolumn{2}{|l|}{ Police :(Par défaut) Times New Roman } \\
\hline $\begin{array}{ll}\text { Page } 14:[109] \text { Mis en forme } & \text { alfonso } \\
\end{array}$ & 27/08/2012 18:23:00 \\
\hline \multicolumn{2}{|l|}{ Police :(Par défaut) Times New Roman, Italique } \\
\hline \begin{tabular}{|ll} 
Page $14:[110]$ Mis en forme & alfonso \\
\end{tabular} & 27/08/2012 18:24:00 \\
\hline \multicolumn{2}{|l|}{ Police :(Par défaut) Times New Roman, Gras } \\
\hline $\begin{array}{ll}\text { Page } 14: \text { : } 111] \text { Mis en forme } & \text { alfonso } \\
\end{array}$ & 27/08/2012 18:23:00 \\
\hline \multicolumn{2}{|l|}{ Police :(Par défaut) Times New Roman } \\
\hline \begin{tabular}{|ll} 
Page $14:$ : [112] Mis en forme & alfonso \\
\end{tabular} & 27/08/2012 18:23:00 \\
\hline \multicolumn{2}{|l|}{ Police :(Par défaut) Times New Roman, Gras } \\
\hline $\begin{array}{ll}\text { Page } 14:[113] \text { Mis en forme } & \text { alfonso } \\
\end{array}$ & 27/08/2012 18:23:00 \\
\hline \multicolumn{2}{|l|}{ Police :(Par défaut) Times New Roman } \\
\hline Page $14:$ [ [114] Mis en forme $\quad$ Olivier GARRAUD & $30 / 12 / 2011$ 17:29:00 \\
\hline \multicolumn{2}{|l|}{ Police :(Par défaut) Times New Roman, 7 pt } \\
\hline Page $14:$ : [114] Mis en forme $\quad$ Olivier GARRAUD & 30/12/2011 17:29:00 \\
\hline \multicolumn{2}{|l|}{ Police :(Par défaut) Times New Roman, 7 pt } \\
\hline Page $14:$ [114] Mis en forme & 30/12/2011 17:29:00 \\
\hline
\end{tabular}


Police :(Par défaut) Times New Roman, 7 pt

\begin{tabular}{|c|c|}
\hline $\begin{array}{ll}\text { Page } 14:[115] \text { Mis en forme } & \text { Olivier GARRAUD } \\
\end{array}$ & 30/12/2011 17:29:00 \\
\hline \multicolumn{2}{|l|}{ Police :(Par défaut) Times New Roman, 7 pt } \\
\hline Page $14:[116]$ Mis en forme & 27/08/2012 18:24:00 \\
\hline \multicolumn{2}{|l|}{ Police :(Par défaut) Times New Roman, Gras, Italique } \\
\hline Page $14:$ [117] Mis en forme & 27/08/2012 18:24:00 \\
\hline \multicolumn{2}{|l|}{ Police :(Par défaut) Times New Roman } \\
\hline Page 14 : [117] Mis en forme & 27/08/2012 18:24:00 \\
\hline \multicolumn{2}{|l|}{ Police :(Par défaut) Times New Roman } \\
\hline Page 14 : [118] Mis en forme & 27/08/2012 18:24:00 \\
\hline \multicolumn{2}{|l|}{ Police :(Par défaut) Times New Roman } \\
\hline Page 14 : [118] Mis en forme & 27/08/2012 18:24:00 \\
\hline \multicolumn{2}{|l|}{ Police :(Par défaut) Times New Roman } \\
\hline Page 14 : [119] Mis en forme & 27/08/2012 18:24:00 \\
\hline \multicolumn{2}{|l|}{ Police :(Par défaut) Times New Roman } \\
\hline Page $14:$ [120] Mis en forme & 27/08/2012 18:24:00 \\
\hline \multicolumn{2}{|l|}{ Police :(Par défaut) Times New Roman, Gras, Italique } \\
\hline Page 14 : [121] Mis en forme & 27/08/2012 18:24:00 \\
\hline \multicolumn{2}{|l|}{ Police :(Par défaut) Times New Roman } \\
\hline Page $14:$ [121] Mis en forme & 27/08/2012 18:24:00 \\
\hline \multicolumn{2}{|l|}{ Police :(Par défaut) Times New Roman } \\
\hline Page $14:$ [122] Mis en forme & 27/08/2012 18:24:00 \\
\hline \multicolumn{2}{|l|}{ Police :(Par défaut) Times New Roman } \\
\hline Page $14:[122]$ Mis en forme & 27/08/2012 18:24:00 \\
\hline \multicolumn{2}{|l|}{ Police :(Par défaut) Times New Roman } \\
\hline Page $14:[123]$ Mis en forme & 27/08/2012 18:24:00 \\
\hline \multicolumn{2}{|l|}{ Police :(Par défaut) Times New Roman } \\
\hline \begin{tabular}{|ll} 
Page $14:$ [ $[124]$ Mis en forme & alfonso \\
\end{tabular} & 27/08/2012 18:24:00 \\
\hline \multicolumn{2}{|l|}{ Police :(Par défaut) Times New Roman, Gras, Italique } \\
\hline $\begin{array}{ll}\text { Page } 14:[125] \text { Mis en forme } & \text { alfonso } \\
\end{array}$ & 27/08/2012 18:24:00 \\
\hline \multicolumn{2}{|l|}{ Police :(Par défaut) Times New Roman } \\
\hline Page $14:[125]$ Mis en forme & 27/08/2012 18:24:00 \\
\hline \multicolumn{2}{|l|}{ Police :(Par défaut) Times New Roman } \\
\hline Page $14:[126]$ Mis en forme & 27/08/2012 18:24:00 \\
\hline \multicolumn{2}{|l|}{ Police :(Par défaut) Times New Roman } \\
\hline Page $14:[126]$ Mis en forme & 27/08/2012 18:24:00 \\
\hline \multicolumn{2}{|l|}{ Police :(Par défaut) Times New Roman } \\
\hline Page $14:[127]$ Mis en forme & 27/08/2012 18:24:00 \\
\hline \multicolumn{2}{|l|}{ Police :(Par défaut) Times New Roman } \\
\hline Page $14:$ [ 128$]$ Mis en forme $\quad$ Olivier GARRAUD & $30 / 12 / 2011$ 17:29:00 \\
\hline \multicolumn{2}{|l|}{ Police :(Par défaut) Times New Roman, 7 pt } \\
\hline $\begin{array}{ll}\text { Page } 14:[129] \text { Mis en forme } & \text { alfonso } \\
\end{array}$ & 27/08/2012 18:24:00 \\
\hline \multicolumn{2}{|l|}{ Police :(Par défaut) Times New Roman, Gras, Italique } \\
\hline Page $14:[130]$ Mis en forme & 27/08/2012 18:24:00 \\
\hline
\end{tabular}


Police :(Par défaut) Times New Roman

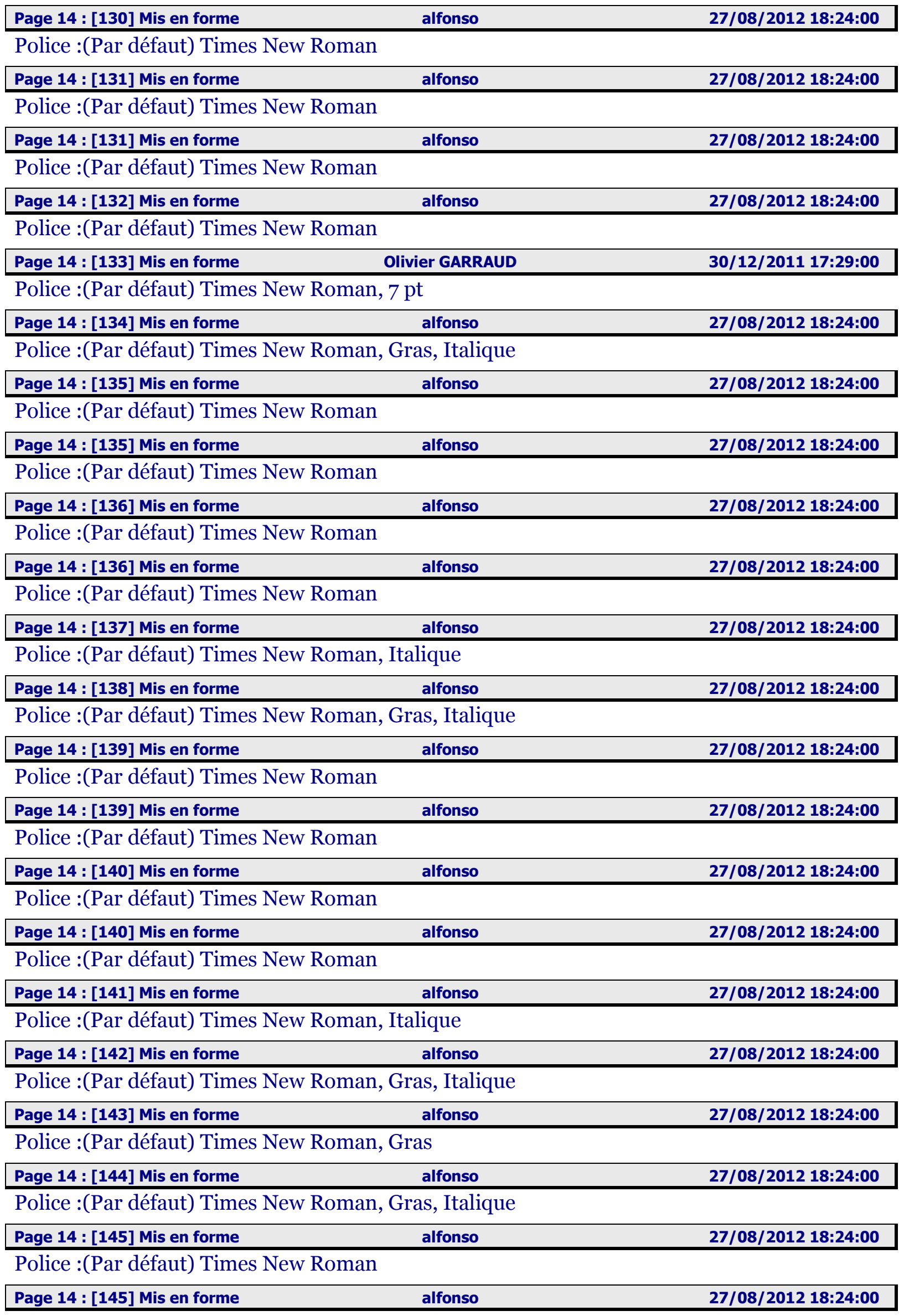


Police :(Par défaut) Times New Roman

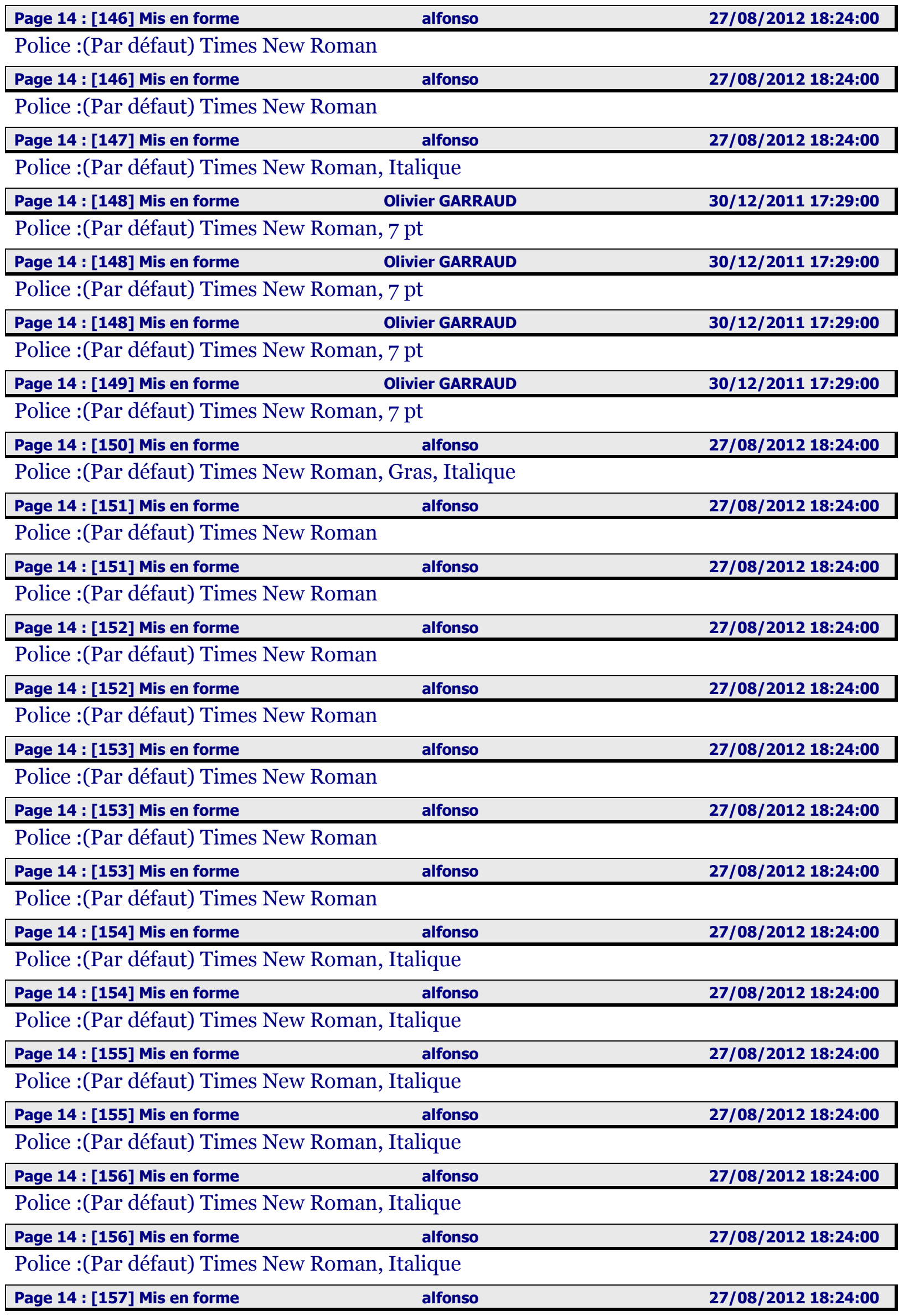


Police :(Par défaut) Times New Roman, Italique

Page $14:$ [157] Mis en forme alfonso

Police :(Par défaut) Times New Roman, Italique

Page $14:$ [158] Mis en forme alfonso

Police :(Par défaut) Times New Roman, Italique

\begin{tabular}{|c|c|c|}
\hline Page 14 : [158] Mis en forme & alfonso & $27 / 08 / 201218: 24: 00$ \\
\hline \multicolumn{3}{|c|}{ Police :(Par défaut) Times New Roman, Italique } \\
\hline Page 14 : [159] Mis en forme & alfonso & $27 / 08 / 201218: 24: 00$ \\
\hline \multicolumn{3}{|c|}{ Police :(Par défaut) Times New Roman, Gras, Italique } \\
\hline Page 14 : [160] Mis en forme & alfonso & $27 / 08 / 201218: 24: 00$ \\
\hline \multicolumn{3}{|c|}{ Police :(Par défaut) Times New Roman } \\
\hline Page 14 : [160] Mis en forme & alfonso & 27/08/2012 18:24:00 \\
\hline \multicolumn{3}{|c|}{ Police :(Par défaut) Times New Roman } \\
\hline Page 14 : [161] Mis en forme & alfonso & $27 / 08 / 201218: 24: 00$ \\
\hline \multicolumn{3}{|c|}{ Police :(Par défaut) Times New Roman } \\
\hline Page $14:$ [161] Mis en forme & alfonso & $27 / 08 / 201218: 24: 00$ \\
\hline \multicolumn{3}{|c|}{ Police :(Par défaut) Times New Roman } \\
\hline Page 14 : [162] Mis en forme & alfonso & $27 / 08 / 201218: 24: 00$ \\
\hline \multicolumn{3}{|c|}{ Police :(Par défaut) Times New Roman } \\
\hline Page 14 : [162] Mis en forme & alfonso & $27 / 08 / 201218: 24: 00$ \\
\hline \multicolumn{3}{|c|}{ Police :(Par défaut) Times New Roman } \\
\hline Page $14:$ [162] Mis en forme & alfonso & $27 / 08 / 2012$ 18:24:00 \\
\hline \multicolumn{3}{|c|}{ Police :(Par défaut) Times New Roman } \\
\hline Page 14 : [163] Mis en forme & alfonso & $27 / 08 / 201218: 24: 00$ \\
\hline
\end{tabular}

Police :(Par défaut) Times New Roman, Italique

Page 14 : [163] Mis en forme alfonso

27/08/2012 18:24:00

Police :(Par défaut) Times New Roman, Italique

\begin{tabular}{|c|c|}
\hline Page $14:[164]$ Mis en forme & $27 / 08 / 201218: 24: 00$ \\
\hline \multicolumn{2}{|l|}{ Police :(Par défaut) Times New Roman, Italique } \\
\hline Page 14 : [164] Mis en forme & $27 / 08 / 201218: 24: 00$ \\
\hline \multicolumn{2}{|l|}{ Police :(Par défaut) Times New Roman, Italique } \\
\hline Page $14:$ [165] Mis en forme & $27 / 08 / 201218: 24: 00$ \\
\hline \multicolumn{2}{|l|}{ Police :(Par défaut) Times New Roman, Italique } \\
\hline Page $14:[165]$ Mis en forme $\quad$ alfonso & $27 / 08 / 201218: 24: 00$ \\
\hline \multicolumn{2}{|l|}{ Police :(Par défaut) Times New Roman, Italique } \\
\hline Page 14: [166] Mis en forme alfonso & 27/08/2012 18:24:00 \\
\hline \multicolumn{2}{|l|}{ Police :(Par défaut) Times New Roman, Italique } \\
\hline Page $14:[166]$ Mis en forme $\quad$ alfonso & $27 / 08 / 201218: 24: 00$ \\
\hline \multicolumn{2}{|l|}{ Police :(Par défaut) Times New Roman, Italique } \\
\hline Page $14:[167]$ Mis en forme $\quad$ alfonso & $27 / 08 / 201218: 24: 00$ \\
\hline \multicolumn{2}{|l|}{ Police :(Par défaut) Times New Roman, Italique } \\
\hline Page $14:[167]$ Mis en forme $\quad$ alfonso & $27 / 08 / 201218: 24: 00$ \\
\hline \multicolumn{2}{|l|}{ Police :(Par défaut) Times New Roman, Italique } \\
\hline Page $14:[168]$ Mis en forme $\quad$ alfonso & $27 / 08 / 201218: 24: 00$ \\
\hline
\end{tabular}


Police :(Par défaut) Times New Roman, Gras, Italique

\begin{tabular}{|c|c|c|}
\hline Page 14: [169] Mis en forme & alfonso & $27 / 08 / 2012$ 18:24:00 \\
\hline \multicolumn{3}{|c|}{ Police :(Par défaut) Times New Roman } \\
\hline Page $14:$ [169] Mis en forme & alfonso & 27/08/2012 18:24:00 \\
\hline \multicolumn{3}{|c|}{ Police :(Par défaut) Times New Roman } \\
\hline Page $14:$ [170] Mis en forme & alfonso & $27 / 08 / 201218: 24: 00$ \\
\hline \multicolumn{3}{|c|}{ Police :(Par défaut) Times New Roman } \\
\hline Page $14:$ [170] Mis en forme & alfonso & 27/08/2012 18:24:00 \\
\hline \multicolumn{3}{|c|}{ Police :(Par défaut) Times New Roman } \\
\hline Page 14 : [171] Mis en forme & alfonso & $27 / 08 / 2012$ 18:24:00 \\
\hline \multicolumn{3}{|c|}{ Police :(Par défaut) Times New Roman } \\
\hline Page 14 : [171] Mis en forme & alfonso & 27/08/2012 18:24:00 \\
\hline \multicolumn{3}{|c|}{ Police :(Par défaut) Times New Roman } \\
\hline Page 14 : [171] Mis en forme & alfonso & $27 / 08 / 2012$ 18:24:00 \\
\hline \multicolumn{3}{|c|}{ Police :(Par défaut) Times New Roman } \\
\hline Page $14:$ [172] Mis en forme & alfonso & 27/08/2012 18:24:00 \\
\hline \multicolumn{3}{|c|}{ Police :(Par défaut) Times New Roman, Italique } \\
\hline Page $14:[172]$ Mis en forme & alfonso & 27/08/2012 18:24:00 \\
\hline \multicolumn{3}{|c|}{ Police :(Par défaut) Times New Roman, Italique } \\
\hline Page 14 : [173] Mis en forme & alfonso & 27/08/2012 18:24:00 \\
\hline \multicolumn{3}{|c|}{ Police :(Par défaut) Times New Roman, Italique } \\
\hline Page $14:[173]$ Mis en forme & alfonso & 27/08/2012 18:24:00 \\
\hline \multicolumn{3}{|c|}{ Police :(Par défaut) Times New Roman, Italique } \\
\hline Page $14:$ [174] Mis en forme & alfonso & 27/08/2012 18:24:00 \\
\hline \multicolumn{3}{|c|}{ Police :(Par défaut) Times New Roman, Italique } \\
\hline Page $14:$ [174] Mis en forme & alfonso & 27/08/2012 18:24:00 \\
\hline \multicolumn{3}{|c|}{ Police :(Par défaut) Times New Roman, Italique } \\
\hline Page $14:[175]$ Mis en forme & alfonso & 27/08/2012 18:24:00 \\
\hline \multicolumn{3}{|c|}{ Police :(Par défaut) Times New Roman, Italique } \\
\hline Page $14:[175]$ Mis en forme & alfonso & 27/08/2012 18:24:00 \\
\hline \multicolumn{3}{|c|}{ Police :(Par défaut) Times New Roman, Italique } \\
\hline Page $14:[176]$ Mis en forme & alfonso & 27/08/2012 18:24:00 \\
\hline \multicolumn{3}{|c|}{ Police :(Par défaut) Times New Roman, Italique } \\
\hline Page $14:[176]$ Mis en forme & alfonso & 27/08/2012 18:24:00 \\
\hline \multicolumn{3}{|c|}{ Police :(Par défaut) Times New Roman, Italique } \\
\hline Page $14:[177]$ Mis en forme & alfonso & 27/08/2012 18:24:00 \\
\hline \multicolumn{3}{|c|}{ Police :(Par défaut) Times New Roman, Gras, Italique } \\
\hline Page $14:$ [178] Mis en forme & alfonso & $27 / 08 / 2012$ 18:24:00 \\
\hline \multicolumn{3}{|c|}{ Police :(Par défaut) Times New Roman } \\
\hline Page $14:[178]$ Mis en forme & alfonso & 27/08/2012 18:24:00 \\
\hline \multicolumn{3}{|c|}{ Police :(Par défaut) Times New Roman } \\
\hline Page $14:$ [179] Mis en forme & alfonso & 27/08/2012 18:24:00 \\
\hline \multicolumn{3}{|c|}{ Police :(Par défaut) Times New Roman } \\
\hline Page $14:$ [179] Mis en forme & alfonso & $27 / 08 / 201218: 24: 00$ \\
\hline
\end{tabular}


Police :(Par défaut) Times New Roman

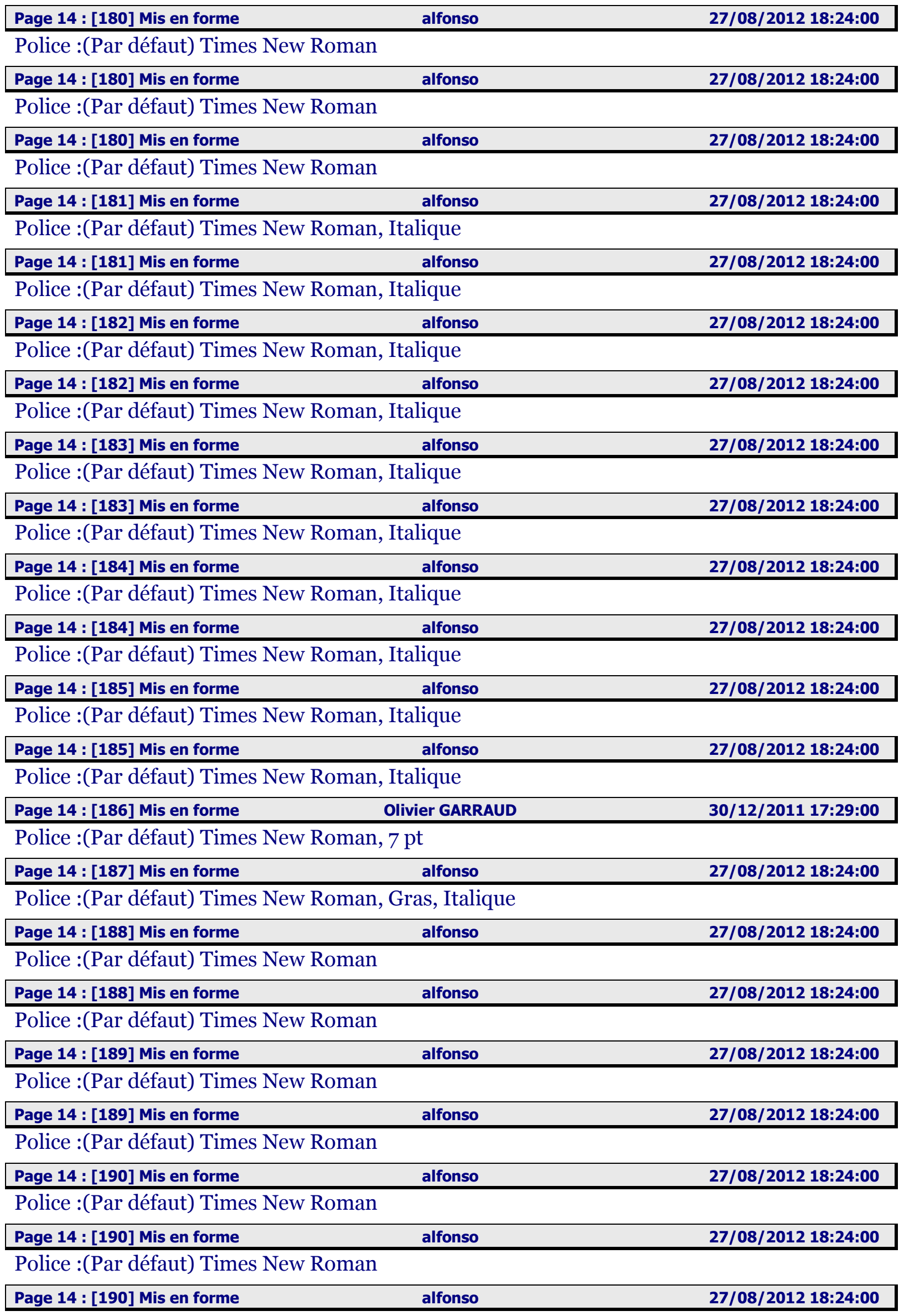


Police :(Par défaut) Times New Roman

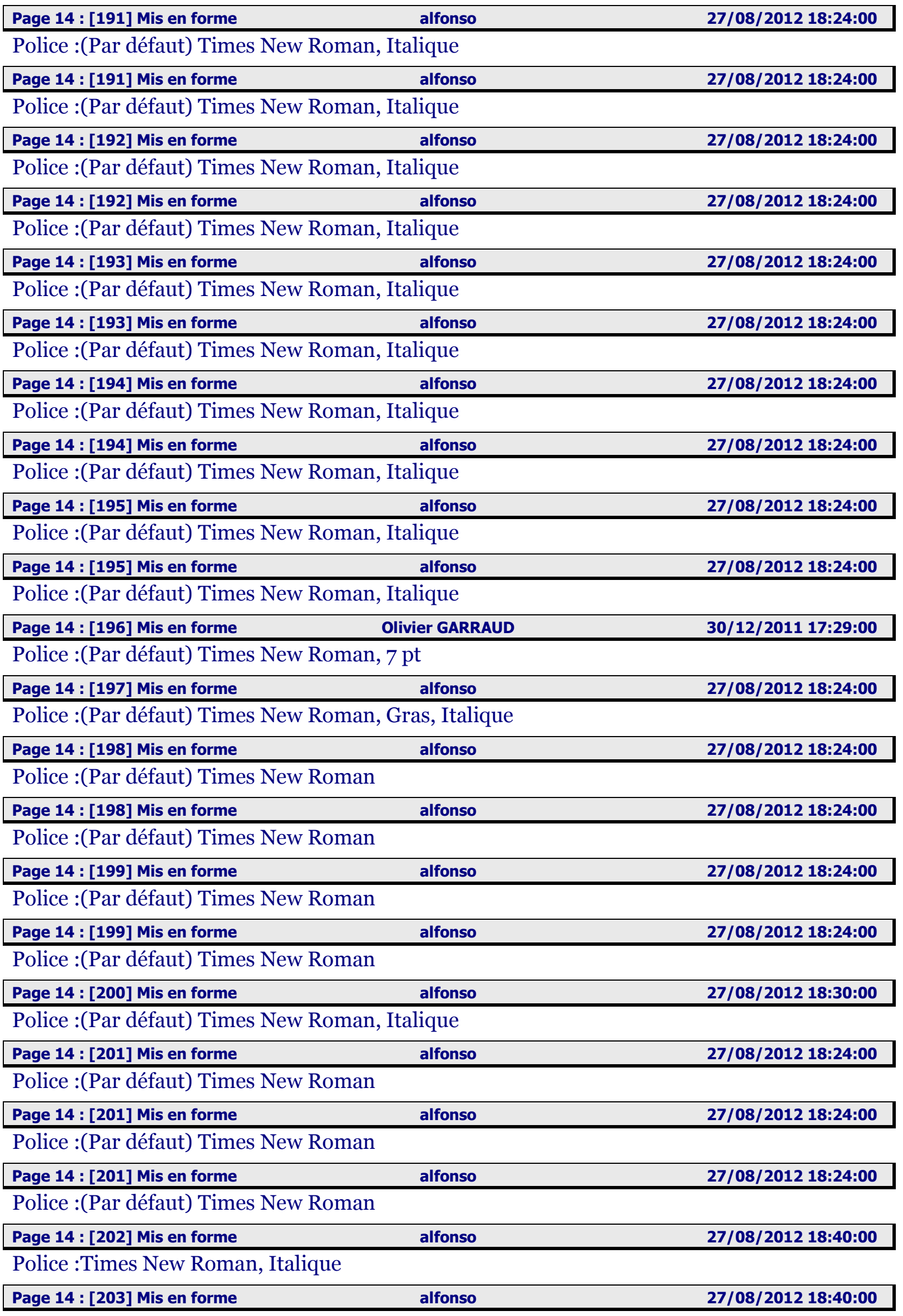


Police :Times New Roman, Italique

\begin{tabular}{|c|c|c|}
\hline Page 14: [204] Mis en forme & alfonso & $27 / 08 / 201218: 40: 00$ \\
\hline \multicolumn{3}{|c|}{ Police :Times New Roman, Gras, Italique } \\
\hline Page $14:$ [205] Mis en forme & alfonso & $27 / 08 / 2012$ 18:40:00 \\
\hline \multicolumn{3}{|c|}{ Police :Times New Roman, Italique } \\
\hline Page $14:$ [206] Mis en forme & alfonso & $27 / 08 / 2012$ 18:40:00 \\
\hline \multicolumn{3}{|c|}{ Police :Times New Roman, Italique } \\
\hline Page $14:$ [207] Mis en forme & alfonso & 27/08/2012 18:40:00 \\
\hline \multicolumn{3}{|c|}{ Police :Times New Roman, Italique } \\
\hline Page $14:$ [208] Mis en forme & alfonso & $27 / 08 / 2012$ 18:40:00 \\
\hline \multicolumn{3}{|c|}{ Police :Times New Roman, Italique } \\
\hline Page 14 : [209] Mis en forme & alfonso & 27/08/2012 18:40:00 \\
\hline \multicolumn{3}{|c|}{ Police :Times New Roman, Italique } \\
\hline Page $14:[210]$ Mis en forme & alfonso & $27 / 08 / 2012$ 18:40:00 \\
\hline \multicolumn{3}{|l|}{ Police :Italique } \\
\hline Page 14 : [211] Mis en forme & alfonso & 27/08/2012 18:40:00 \\
\hline \multicolumn{3}{|c|}{ Police :Times New Roman, Italique } \\
\hline Page $14:$ [212] Mis en forme & alfonso & 27/08/2012 18:40:00 \\
\hline \multicolumn{3}{|c|}{ Police :Times New Roman, Italique } \\
\hline Page $14:$ [213] Mis en forme & alfonso & 27/08/2012 18:40:00 \\
\hline \multicolumn{3}{|c|}{ Police :Times New Roman, Gras, Italique } \\
\hline Page $14:$ [214] Mis en forme & alfonso & 27/08/2012 18:40:00 \\
\hline \multicolumn{3}{|c|}{ Police :Times New Roman, Italique } \\
\hline Page $14:[215]$ Mis en forme & alfonso & 27/08/2012 18:40:00 \\
\hline \multicolumn{3}{|c|}{ Police :Times New Roman, Italique } \\
\hline Page $14:$ [216] Mis en forme & alfonso & 27/08/2012 18:40:00 \\
\hline \multicolumn{3}{|c|}{ Police :Times New Roman, Italique } \\
\hline Page $14:$ [217] Mis en forme & alfonso & 27/08/2012 18:40:00 \\
\hline \multicolumn{3}{|c|}{ Police :Times New Roman, Italique } \\
\hline Page $14:$ [218] Mis en forme & alfonso & 27/08/2012 18:40:00 \\
\hline \multicolumn{3}{|c|}{ Police :Times New Roman, Italique } \\
\hline Page 14 : [219] Mis en forme & alfonso & $27 / 08 / 201218: 40: 00$ \\
\hline
\end{tabular}

Police :Italique 